\title{
Stereoselective Addition of Chiral Titanium Enolates to 5-Substituted Five-Membered Oxocarbenium Ions
}

\author{
Ronaldo A. Pilli ${ }^{*, a}$ and Valéria B. Riatto ${ }^{b}$ \\ ${ }^{a}$ Instituto de Química, Universidade Estadual de Campinas, 13083-970 Campinas-SP, Brazil \\ ${ }^{b}$ Faculdade de Saúde, Centro Universitário da Bahia, 41770-130 Salvador-BA, Brazil
}

\begin{abstract}
O curso estereoquímico da adição de enolatos de titânio quirais a $\gamma$-lactóis derivados do ácido (S)-glutâmico foi investigado. Quando $\gamma$-lactóis 5-substituídos foram tratados com enolatos de titânio quirais derivados de $\mathrm{N}$-acetil-, $\mathrm{N}$-propionil-, $\mathrm{N}$-bromoacetil- e $\mathrm{N}$-fenilacetil oxazolidin-2onas somente dois diastereoisômeros foram obtidos, revelando um completo controle facial pelo enolato de titânio, enquanto que a discriminação facial do íon oxocarbênio mostrou-se dependente da natureza do grupo $\mathrm{R}^{3}$ do enolato. Dessililação com $\mathrm{HF} / \mathrm{CH}_{3} \mathrm{CN}$ aquoso, seguida de redução com $\mathrm{LiBH}_{4}$, forneceu eficientemente dióis tetraidrofurânicos trans-2,5-dissubstituídos e recuperação do auxiliar quiral.
\end{abstract}

The sterochemical outcome of the addition of chiral titanium enolates to $\gamma$-lactols derived from $(S)$-glutamic acid were examined. When 5 -substituted $\gamma$-lactols were treated with chiral titanium enolates of $\mathrm{N}$-acetyl-, $\mathrm{N}$-propionyl-, $\mathrm{N}$-bromoacetyl- and $\mathrm{N}$-phenylacetyl oxazolidin-2ones, only two diastereoisomers were obtained, revealing complete facial control by the chiral titanium enolate while the oxocarbenium ion facial discrimination was dependent on the nature of the enolate $\mathrm{R}^{3}$ substituent. After desilylation with aqueous $\mathrm{HF} / \mathrm{CH}_{3} \mathrm{CN}, \mathrm{LiBH}_{4}$ reduction allowed the efficient preparation of the corresponding trans-2,5-disubstituted tetrahydrofuran diols and recovery of the chiral auxiliary.

Keywords: oxocarbenium ions, chiral titanium enolates, trans-2,5-disubstituted tetrahydrofurans

\section{Introduction}

The stereoselective synthesis of 2,5-substituted tetrahydrofurans through nucleophilic addition to fivemembered ring oxocarbenium ions represents an important route to a variety of biologically important natural products including polyether inophore antibiotics ${ }^{1}$ and acetogenins. ${ }^{2-7}$ These substances exhibit a diverse range of biological activities including antitumor, antihelmintic, antimalarial, antimicrobial, and antiprotozoal activities. Due to the importance of these molecules, considerable effort has been devoted toward the development of methods for the stereoselective construction of 2,5-substituted tetrahydrofurans. Addition of nucleophiles such as Grignard reagents, ${ }^{8}$ organozinc reagents, ${ }^{9}$ and titanium enolates ${ }^{10,11}$ to oxocarbenium ions derived from $\gamma$-lactol derivatives have

*e-mail: pilli@iqm.unicamp.br been broadly employed in the stereoselective construction of tetrahydrofurans. ${ }^{12-14}$

Recent studies have led to the development of models to explain and predict the stereochemical outcome of nucleophilic additions to oxocarbenium ions. Reissig and co-workers have developed a transition state model that accounts for the stereochemical outcome of the addition of allylsilanes and silyl enol ethers to phenyl- and methyl substituted $\gamma$-lactols. ${ }^{15-18}$ This rationalization was based on the extension of the Felkin-Anh ${ }^{19-20}$ model and do not encompass a wide range of substrates, nucleophiles and conditions.

Woerpel has developed a complementary model for nucleophilic addition to 5-membered cyclic oxocarbenium ions which suggests that addition preferentially occurs from the concave face of the envelope conformation of the oxocarbenium ion. ${ }^{21-25}$ The preference for the "inside attack' from the concave face is believed to result from stereoelectronic effect. This model requires attack of 
the nucleophile to the face of the oxocarbenium ion that provides the products in their lowest energy staggered conformations. Small nucleophiles add to the 'inside' of the lower energy ground-state conformer of the oxocarbenium ion. In contrast, sterically demanding nucleophiles add to the inside of the envelope conformer where approach is anti to the substituent of the oxocarbenium ion, regardless of the ground-state conformer population.

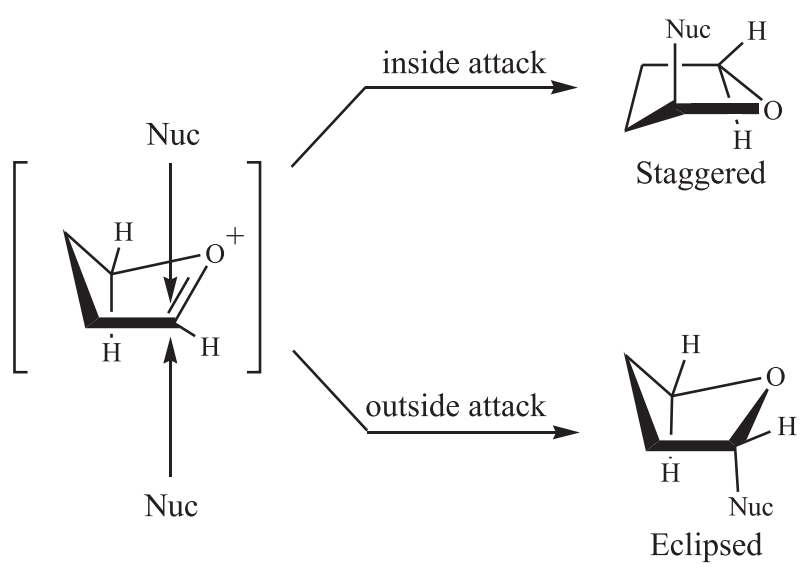

Although a variety of nucleophiles have been utilized for 2,5-substituted tetrahydrofuran synthesis via addition to cyclic oxocarbenium ions, studies involving the stereoselective addition of chiral and prochiral nucleophiles are scarce. ${ }^{26}$

During the course of our study of stereoselective synthesis of 2,5-substituted tetrahydrofurans through nucleophilic addition to five-membered ring oxocarbenium ions, we have reported the stereoselective Lewis acid-promoted allylsilane substitution reaction at the anomeric carbon of $\gamma$-lactol 1a with preparatively useful trans-2,5 selectivity being observed when a more hindered nucleophile was employed (Scheme 1). ${ }^{27}$
Taking into account the high facial discrimination displayed by stereochemically defined titanium enolates in aldol reaction ${ }^{28}$ and in their addition to cyclic $N$-acyliminium ions, ${ }^{29,30}$ we have previously studied the reactivity of the titanium enolate of chiral oxazolidinones with the chiral oxocarbenium ion derived from 5 -substituted- $\gamma$-lactol 1a regarding the generation of the stereogenic centers (C-2 and C-2' in Scheme 2). ${ }^{11}$ In continuation of our work on the synthesis of trans-2,5-disubtituted tetrahydrofurans, we report here full details of the diastereoselective additions of stereochemically defined titanium enolates of chiral oxazolidinones to cyclic oxocarbenium ions together with the dependence of the diastereoselectivity on the substitution pattern of $\gamma$-lactol and the nature of the $\mathrm{R}^{3}$ group in the enolate. A model which accounts for the observed diastereoselectivity is proposed.

\section{Results and Discussion}

Lactols 1a-d were prepared from $\gamma$-butyrolactones 8a-d ${ }^{31}$ via DIBAL-H reduction at low temperature as a $2: 1$ epimeric mixtures (Scheme 3).

The reaction of lactol 1b with achiral titanium (IV) enolate $\mathbf{1 0}$ from oxazolidinone $\mathbf{9}$ was first examined. The chlorotitanium enolate was generated by the sequential addition of 1.1 equiv. of $\mathrm{TiCl}_{4}$ and 1.1 equiv. of diisopropylethylamine (DIPEA) to a cold solution $\left(-23^{\circ} \mathrm{C}\right)$ of $\mathrm{N}$-propionyl oxazolidin-2-one 9 in $\mathrm{CH}_{2} \mathrm{Cl}_{2}$, followed by the addition of a $\mathrm{CH}_{2} \mathrm{Cl}_{2}$ solution of lactol $\mathbf{1 b}$ at $-23{ }^{\circ} \mathrm{C}$. Under these conditions the OTES group proved to be labile and we were not able to isolate the coupling products. We then moved to a more robust and bulkier silyl group (OTBS) and the reaction of chlorotitanium enolate $\mathbf{1 0}$ and lactol 1c, under the same experimental conditions, afforded a 4:4:1:1 mixture of the four possible adducts (trans-11/trans-12/ cis-11/cis-12, determined by ${ }^{1} \mathrm{H}$ NMR) in 52\% yield

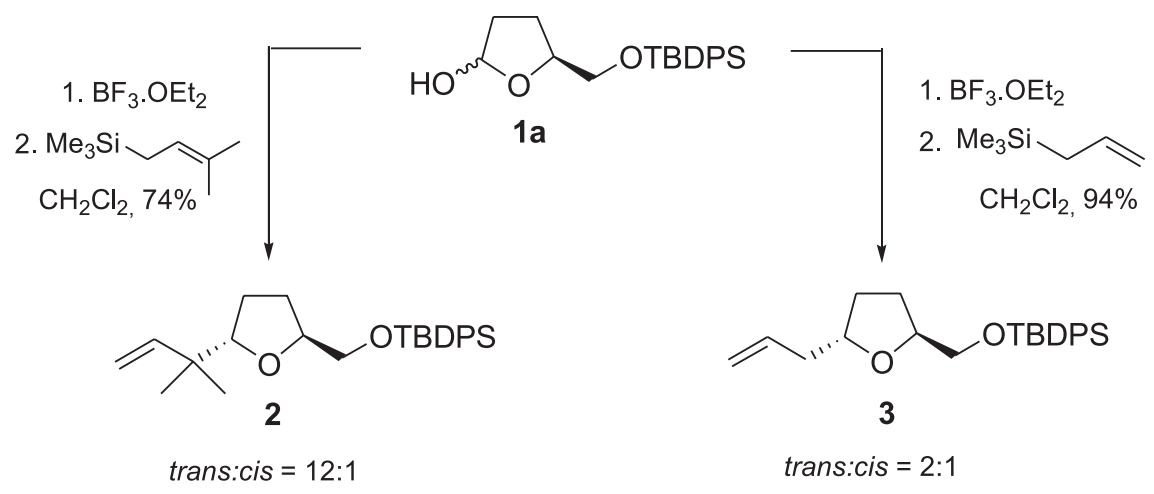

Scheme 1. 
<smiles>CCC(=O)N1C(=O)OCC1Br</smiles>

$\mathrm{TiCl}_{4}$, DIPEA $\mathrm{CH}_{2} \mathrm{Cl}_{2},-23^{\circ} \mathrm{C}$<smiles>[R]C=C1O[Al](Cl)OC2OCC(Cc3cccs3)N12</smiles><smiles>CCC(=O)N1C(=O)OC[C@H]1Cc1ccccc1</smiles>

$\mathrm{TiCl}_{4}$, DIPEA $\mathrm{CH}_{2} \mathrm{Cl}_{2},-23^{\circ} \mathrm{C}$<smiles>[R]C=C1O[Al](Cl)OC2OCC(Cc3ccccc3)N12</smiles>

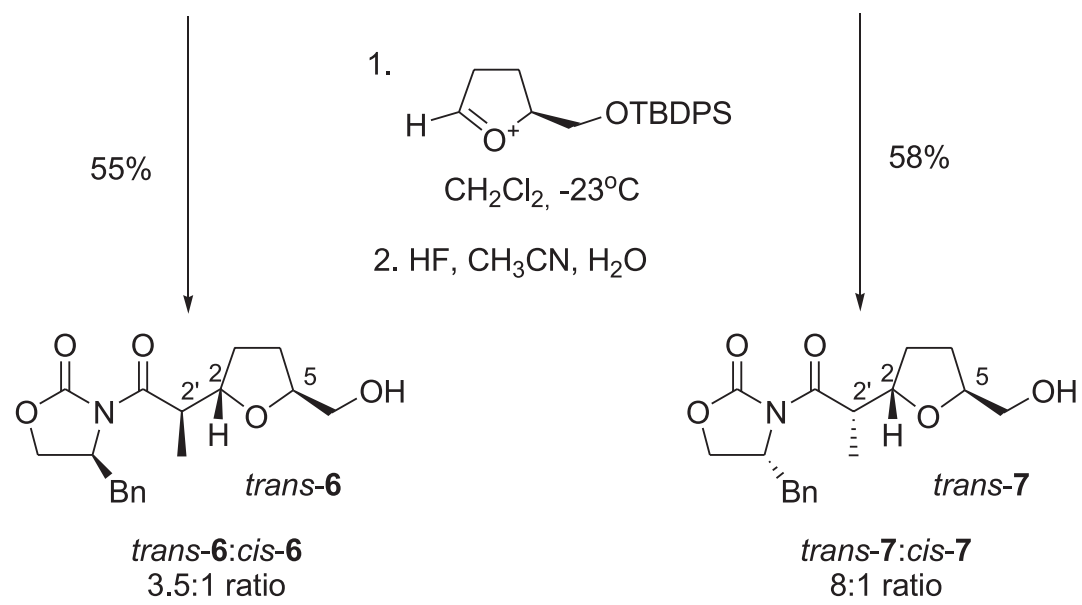

Scheme 2.<smiles>C#CCC(N)C(=O)O</smiles>

(S)-glutamic acid<smiles>O=C1CCC(C[PH2+])O1</smiles>

8a: $P=T B D P S$

8b: $P=T E S$ 8c: $P=T B S$<smiles></smiles>

$8 d$<smiles>CCCCCCCCCCC</smiles>

$-78^{\circ} \mathrm{C}$

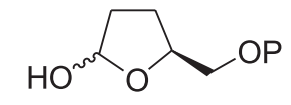

1a: $P=$ TBDPS, $99 \%$

1b: $P=T E S, 84 \%$

1c: $P=T B S, 90 \%$

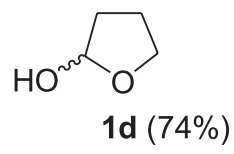

Scheme 3 .

(Scheme 4). The use of a more sterically demanding group (OTBDPS) in the lactol was accompanied by an increase in the yield of trans-13/trans-14/cis-13/cis-14 (61\%) without any impact on the diastereoisomeric ratio $(4: 4: 1: 1)$.
The major isomers trans-13 and trans-14 were separated by column chromatography on silica gel and had their configuration determined after conversion to the corresponding diols (TBDPS deprotection and reduction 
with $\mathrm{LiBH}_{4}$ ) which were shown to be identical to $\mathbf{1 5}$ and 16, respectively (Scheme 5), derived from trans-6 and trans-7 which were synthesized and had their structures established by X-ray diffraction analyses in a preceding work. ${ }^{11}$ Compounds trans-11 and trans-12 afforded the same diols $\mathbf{1 5}$ and 16, obtained previously from trans-13 and trans-14, respectively.

In order to evaluate the influence of the substituent in the $\mathrm{C}-5$ position of the $\gamma$-lactol, we examined the addition of chiral titanium (IV) enolates derived from $(\boldsymbol{R})-\mathbf{1 4}$ and (R)-4 oxazolidinones to unsubstituted lactol 1d (Scheme 6). The reactions afforded only two diastereoisomers in 2.3:1 (syn-17/anti-17) and 1:1 (syn-18/anti-18) ratios (determined by ${ }^{1} \mathrm{H}$ NMR), respectively.

These results confirm complete facial control by the chiral chlorotitanium enolates derived from $(\boldsymbol{R})-\mathbf{4}$ and (R)-14 as only two out of the four possible diastereoisomers were formed in their reactions with lactol $\mathbf{1 d}$.

The configuration of the new stereocenter C-2' was assumed to be $S$ when $(R)$-oxazolidinones were used on the basis of the known stereochemical outcome of the reaction of the chiral titanium enolates derived from 1,3-oxazolidin-2-ones and related chiral titanium enolates with substrates able to react via a $S_{N} 1$ pathway, which affords complete enolate facial control in that position. ${ }^{28-30}$ Furthermore, upon inspection of the ${ }^{1} \mathrm{H}$ NMR spectra of the 2,5-disubstituted tetrahydrofurans obtained previously, ${ }^{11}$ it became apparent that the vicinal coupling constant ${ }^{3} J_{2,2}$, was diagnostic of their relative stereochemistry with ${ }^{3} J_{2,2}$, being larger in the syn series $(9.0-10.0 \mathrm{~Hz})$ than in the anti series $(6.0-8.2 \mathrm{~Hz})$ which suggests that these compounds exhibit a conformational preference.

The major diastereoisomer syn-17 was separated by column chromatography and the configuration 2' $S, 2 S$ was tentatively assigned based on the magnitude of the vicinal coupling constant $\left({ }^{3} J_{2,2^{\prime}}=9.7 \mathrm{~Hz}\right)$ while for the minor isomer anti-17 $\left({ }^{3} J_{2,2^{\prime}}=7.0 \mathrm{~Hz}\right)$, the configuration 2 ' $S, 2 R$ was proposed. The absolute configuration at C-2' was conserved in both of them. On the other hand, the chiral oxocarbenium ions derived from $\mathbf{1 a}$ and $\mathbf{1 c}$ were less efficient in chiral discrimination as a mixture of the four possible stereoisomers were formed in their reactions with achiral chlorotitanium enolate $\mathbf{1 0}$ with the silyloxymethyl group at C-5 steering the preferential trans addition of the nucleophile.

In order to improve the diastereoisomeric ratio observed in the reaction involving lactol 1a, we examined the impact of chiral titanium (IV) enolates derived from oxazolidinones $(R)-4,(S)-4,(R)-14,(R)-19,(S)-19$ and $(\boldsymbol{R}) \mathbf{2 0}$ in the process (Table 1).

In fact, the addition of titanium (IV) enolates derived from $(\boldsymbol{R})-\mathbf{4}\left(\mathrm{R}^{3}=\mathrm{Me}\right),(\boldsymbol{R})-\mathbf{1 4}\left(\mathrm{R}^{3}=\mathrm{Br}\right)$ and $(\boldsymbol{R})-\mathbf{1 9}$ $\left(\mathrm{R}^{3}=\mathrm{Ph}\right)$ to lactol 1a afforded only two diastereoisomers in 8:1, 10:1 and 7:1 ratios, respectively (Table 1, entries 2,3 and 5). After TBDPS group deprotection, the major diastereoisomers trans-7 and trans-21 were separated by column chromatography, recrystallized $\left(\mathrm{CH}_{2} \mathrm{Cl}_{2}\right)$ and had their absolute stereochemistry established by

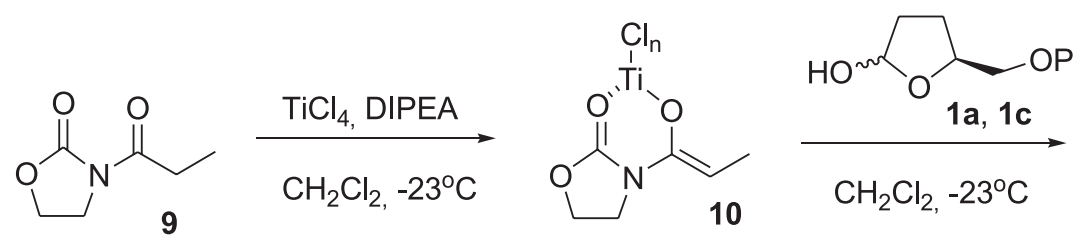

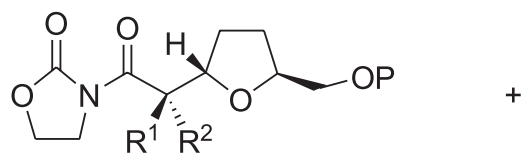

trans-11: $\mathrm{R}^{1}=\mathrm{CH}_{3}, \mathrm{R}^{2}=\mathrm{H}, \mathrm{P}=\mathrm{TBS}$ trans-12: $\mathrm{R}^{1}=\mathrm{H}, \mathrm{R}^{2}=\mathrm{CH}_{3}, \mathrm{P}=\mathrm{TBS}$ trans-13: $\mathrm{R}^{1}=\mathrm{CH}_{3}, \mathrm{R}^{2}=\mathrm{H}, \mathrm{P}=\mathrm{TBDPS}$ trans-14: $\mathrm{R}^{1}=\mathrm{H}, \mathrm{R}^{2}=\mathrm{CH}_{3}, \mathrm{P}=\mathrm{TBDPS}$

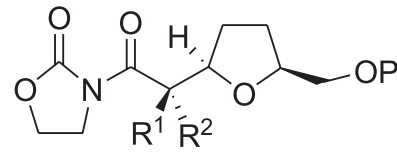

cis-11: $\mathrm{R}^{1}=\mathrm{CH}_{3}, \mathrm{R}^{2}=\mathrm{H}, \mathrm{P}=\mathrm{TBS}$

cis-12: $\mathrm{R}^{1}=\mathrm{H}, \mathrm{R}^{2}=\mathrm{CH}_{3}, \mathrm{P}=\mathrm{TBS}$

cis-13: $\mathrm{R}^{1}=\mathrm{CH}_{3}, \mathrm{R}^{2}=\mathrm{H}, \mathrm{P}=$ TBDPS

cis-14: $\mathrm{R}^{1}=\mathrm{H}, \mathrm{R}^{2}=\mathrm{CH}_{3}, \mathrm{P}=\mathrm{TBDPS}$

$P=$ TBS, 52\% yeld, trans-11/trans-12/cis-11/cis-12 ratio $=4: 4: 1: 1$

$\mathrm{P}=$ TBDPS, $61 \%$ yeld, trans-13/trans- $14 /$ cis-13/cis-14 ratio $=4: 4: 1: 1$

Scheme 4. 


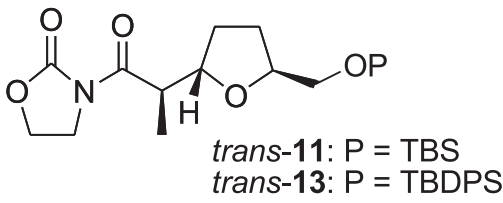

1. $\mathrm{HF}, \mathrm{CH}_{3} \mathrm{CN}, \mathrm{H}_{2} \mathrm{O}$

2. $\mathrm{LiBH}_{4}, \mathrm{MeOH} / \mathrm{THF}$<smiles>C[C@H](CO)[C@H]1CC[C@@H](CO)O1</smiles>

15

$\mathrm{LiBH}_{4}, \mathrm{MeOH} / \mathrm{THF}$<smiles>C[C@H](C(=O)N1C(=O)OCC1Cc1ccccc1)[C@H]1CC[C@@H](CO)O1</smiles>

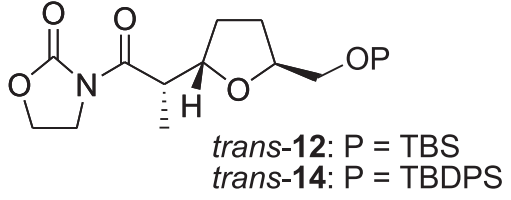

1. $\mathrm{HF}, \mathrm{CH}_{3} \mathrm{CN}, \mathrm{H}_{2} \mathrm{O}$

2. $\mathrm{LiBH}_{4}, \mathrm{MeOH} / \mathrm{THF}$<smiles>C[C@@H](CO)[C@H]1CC[C@@H](CO)O1</smiles>

$\mathrm{LiBH}_{4}, \mathrm{MeOH} / \mathrm{THF}$<smiles>O=C(C[C@H]1CC[C@@H](CO)O1)N1C(=O)OC[C@H]1Br</smiles>

Scheme 5.<smiles>[R]CC(=O)N1C(=O)OC[C@H]1Br</smiles>

(R)-14 $\mathrm{R}^{3}=\mathrm{Br}$ $(R)-4 \mathrm{R}^{3}=\mathrm{Me}$
1. $\mathrm{TiCl}_{4}$, DIPEA,

$\mathrm{CH}_{2} \mathrm{Cl}_{2},-23^{\circ} \mathrm{C}$

2.<smiles>O[C@@H]1CCCO1</smiles>

$\mathrm{CH}_{2} \mathrm{Cl}_{2},-23^{\circ} \mathrm{C}$<smiles></smiles>

syn-17: $\mathrm{R}^{3}=\mathrm{Br}$

syn-18: $\mathrm{R}^{3}=\mathrm{Me}$<smiles>[R]C(Cc1ccccc1)C(=O)N1C(=O)OC[C@H]1Cc1ccco1</smiles>

anti-17: $\mathrm{R}^{3}=\mathrm{Br}$

anti-18: $\mathrm{R}^{3}=\mathrm{Me}$

$\mathrm{R}^{3}=\mathrm{Br}, 54 \%$ yield, syn-17/anti-17 ratio $=2.3: 1$

$\mathrm{R}^{3}=\mathrm{Me}, 67 \%$ yield, syn-18/anti-18 ratio $=1: 1$

Scheme 6.

X-ray diffraction analysis. ${ }^{11}$ The major diastereoisomer trans-23 was separated by column chromatography and the configuration 2' $S, 2 S$ was tentatively assigned based on the magnitude of the vicinal coupling constant $\left({ }^{3} J_{2,2^{\prime}}=10.0 \mathrm{~Hz}\right)$, while for the minor isomer cis-23 the configuration $2 ' S, 2 R$ was proposed $\left({ }^{3} J_{2,2}=8.0 \mathrm{~Hz}\right.$ - Table 1$)$.

The combination of the chlorotitanium enolates derived from $(\boldsymbol{R}) \mathbf{- 4}$ and $(\boldsymbol{R})-\mathbf{1 9}$, and the oxocarbenium ion derived from $(S)$-lactol 1a acted as matched pair (trans-7/cis-7, 8:1 ratio and trans-23/cis-23, 7:1 ratio - Table 1, entries 2 and 5), while the combination of the chlorotitanium enolates derived from $(\boldsymbol{S})-\mathbf{4}$ and $(\boldsymbol{S}) \mathbf{- 1 9}$, and the $(S)$-lactol $\mathbf{1 a}$ acted as mismatched pair (trans-6/cis-6, 3.5:1 ratio and trans-22/cis-22, 5:1 ratio - Table 1, entries 1 and 4). After TBDPS group deprotection with $\mathrm{HF} / \mathrm{CH}_{3} \mathrm{CN}$, the major diastereoisomers trans-6 and trans-22 were separated by column chromatography and their relative configuration were established by inspection of the vicinal coupling constant $\left({ }^{3} J_{2,2^{\prime}}\right.$ - Table 1$)$.

Reduction of some adducts allowed the efficient recovery of the chiral auxiliaries and provided diols $\mathbf{1 5}$, 16, 25 and 26 in good yields (Table 2). 
Table 1. Addition of chlorotitanium enolates derived from $(R)-\mathbf{4},(S)-\mathbf{4},(\boldsymbol{R})-\mathbf{1 4},(\boldsymbol{R})-\mathbf{1 9},(S)-\mathbf{1 9}$ and $(\boldsymbol{R})-\mathbf{2 0}$ to lactol $\mathbf{1 a}$

Entry

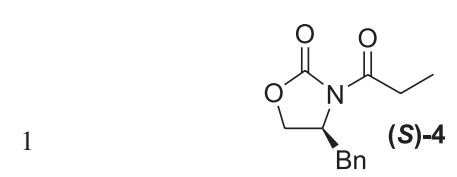

$(S)-4$
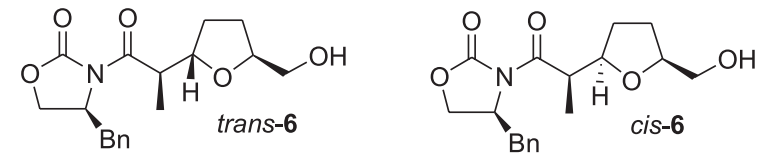

$55 \%$

$(3.5: 1)^{\mathrm{a}}$

$J_{\text {anti }}=6.8 \mathrm{~Hz}$

$J_{s y n}=9.3 \mathrm{~Hz}$<smiles>CCC(=O)N1C(=O)OCC1[Mg]</smiles><smiles>O=C(C[C@@H]1CC[C@@H](CO)O1)N1C(=O)OC[C@H]1Br</smiles><smiles>O=C(CC1CCC(CO)O1)N1C(=O)OCC1Br</smiles>

$J_{\text {syn }}=9.3 \mathrm{~Hz}$<smiles>O=C1OCC2CCCCC12</smiles>

Bn

(R)-14<smiles>O=C1OCC(CO)N1C(=O)C(Br)C1CCC(Cc2ccccc2)O1</smiles>

$J_{\text {syn }}=9.5 \mathrm{~Hz}$<smiles>CC1COC(=O)N1C(=O)C(Br)C1CCC(CO)O1</smiles>

$(10: 1)^{\mathrm{b}}$

$J_{\text {anti }}=6.0 \mathrm{~Hz}$<smiles>O=C(C[Hg]c1ccccc1)N1C(=O)OCC1Cc1ccccc1</smiles><smiles>O=C1OCC(Cc2ccccc2)N1C(=O)C(c1ccccc1)C1CCC(CO)O1</smiles>

$J_{\text {anti }}=8.2 \mathrm{~Hz}$<smiles>O=C1OCC(Cc2ccccc2)N1C(=O)C(c1ccccc1)[C@H]1CCC(CO)O1</smiles>

$J_{s y n}=9.8 \mathrm{~Hz}$<smiles>O=C(Cc1ccccc1)N1C(=O)OC[C@H]1Cc1ccccc1</smiles><smiles></smiles>

$$
J_{\text {syn }}=10.0 \mathrm{~Hz}
$$<smiles>CC1COC(=O)N1C(=O)C(c1ccccc1)C1CCC(CO)O1</smiles>

Bn

$$
J_{\text {anti }}=8.0 \mathrm{~Hz}
$$

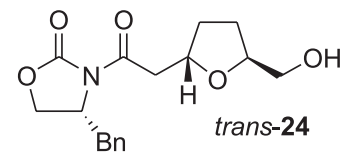

$58 \%$

$58 \%$
$\mathrm{Bn}$

(R)-20

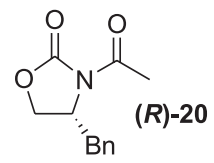

$\mathrm{Bn}$

Bn

cis-24

${ }^{\text {aD }}$ Determined by GC analysis; ${ }^{b}$ Determined in the crude mixture by ${ }^{1} \mathrm{H}$ NMR spectroscopy (500 $\mathrm{MHz}$ ) in $\mathrm{CDCl}_{3}$; ${ }^{\mathrm{c}}$ Yields (two steps) after purification of the crude mixture by filtration through a pad of silica-gel; ${ }^{\mathrm{d} T B D P S}$ group deprotection with HF/pyridine. 
Having established the nature of the matched pair in the coupling reaction, we investigated the use of the chlorotitanium enolate derived from $(\boldsymbol{R})$-20 in the reaction with lactol 1a, which afforded a mixture of the two possible stereoisomers trans-24/cis-24, in a 2:1 ratio, due to the poor facial discrimination of the unsubstituted chlorotitanium enolate (Table 1 - entry 6). However, compound trans-24 can be efficiently obtained when the bromo derivative trans-21 is treated with $n-\mathrm{Bu}_{3} \mathrm{SnH}$ (Scheme 7).

Furthermore, bromo derivative trans-21 is a versatile intermediate for $\alpha$-amino acids synthesis. Reaction of trans-21 with sodium azide in DMF afforded the corresponding azide $\mathbf{2 7}$ in $\mathbf{7 3 \%}$ yield (Scheme 8) which can be converted directly to the corresponding amine by hydrogenation. ${ }^{32}$

Finally, we examined the reactivity of $\alpha-\beta$-insaturated oxocarbenium ion derived from $\gamma$-lactol $1 \mathbf{e}$ prepared via reduction of lactone $8 \mathbf{e}^{33}$ with DIBAL-H at $-78^{\circ} \mathrm{C}$ (Scheme 9).

The addition of a $\mathrm{CH}_{2} \mathrm{Cl}_{2}$ solution of lactol $1 \mathrm{e}$ to the chlorotitanium enolate derived from $(\boldsymbol{R}) \mathbf{- 1 4}$ afforded only two diastereoisomers trans-28/cis-28 in 3.5:1 ratio

Table 2. Preparation of diols 15, 16, 25 and 26

\begin{tabular}{|c|c|c|c|c|}
\hline Entry & Adduct & Diol & Yield (\%) & Chiral Auxiliary Yield (\%) \\
\hline 1 & & 15 & $90^{\mathrm{a}}$ & 86 \\
\hline 2 & & 15 & $88^{\mathrm{b}}$ & 87 \\
\hline 3 & & 15 & 87 & 88 \\
\hline 4 & trans & 16 & $89^{a}$ & 95 \\
\hline 5 & & & $91^{\mathrm{b}}$ & 86 \\
\hline 6 & & 16 & 88 & 73 \\
\hline 7 & & 25 & 88 & 86 \\
\hline 8 & & 26 & 89 & 85 \\
\hline
\end{tabular}

${ }^{a}$ Yield (two steps) after TBDPS group deprotection with $\mathrm{HF} / \mathrm{CH}_{3} \mathrm{CN} / \mathrm{H}_{2} \mathrm{O} ;{ }^{\text {b }}$ Yield (two steps) after TBS group deprotection with $\mathrm{HF} / \mathrm{CH}_{3} \mathrm{CN} / \mathrm{H}_{2} \mathrm{O}$. 
(Scheme 10). The absolute configuration of the major diastereoisomer trans-28 was tentatively assigned based on the vicinal coupling constant $\left({ }^{3} J_{2,2^{\prime}}=9.5 \mathrm{~Hz}\right)$. The bromo derivative trans-28 is a potentially useful intermediate for the preparation of (-)-furanomycin, ${ }^{34}$ the enantiomeric form of the isoleucine antagonist (+)-furanomycin (Scheme 10).

The stereochemical outcome of the reactions investigated seems to be ruled by an open transition state with the favored approach of the less hindered face of a Z-configured internally coordinated titanium enolate to the sterically more available $R e$ face of a putative oxocarbenium ion. Either an antiperiplanar or a synclinal approach of the nucleophile to the oxocarbenium ion seems to be available (Scheme 11).

Similar results observed for the addition of titanium enolate derived of achiral oxazolidinone 9 to lactols 1a and 1c revealed that the protecting group is located at a remote position from the electrophilic center and low steric interactions with the nucleophile are expected. The absence of a chiral substituent in the titanium enolate $\mathbf{1 0}$ led to no discrimination between the two faces (Scheme 11).

When the titanium enolate derived from $(\boldsymbol{R})-\mathbf{4}$ was added to lactol 1d, the absence of a substituent at the 5-position

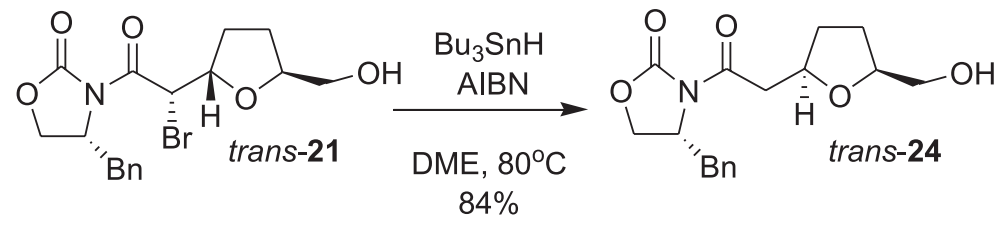

Scheme 7.<smiles>O=C1OC[C@H](Br)N1C(=O)[C@@H](Br)[C@H]1CC[C@@H](CO)O1</smiles>

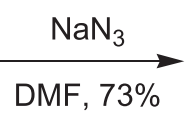<smiles>N[C@@H](C(=O)N1C(=O)OC[C@H]1Br)[C@H]1CC[C@@H](CO)O1</smiles>

Scheme 8.<smiles>O=C1C=CC(CO[SbH2])O1</smiles><smiles>[10BH2][10BH2]</smiles><smiles>[O-][R5](=S)OC[C@@H]1C=C[C@@H](O)O1</smiles>

Scheme 9.<smiles></smiles>

1. $\mathrm{TiCl}_{4}$, DIPEA, $\mathrm{CH}_{2} \mathrm{Cl}_{2},-23^{\circ} \mathrm{C}$

2.<smiles>O[C@@H]1C=CC(CO[SbH2])O1</smiles>

$\mathrm{CH}_{2} \mathrm{Cl}_{2},-23^{\circ} \mathrm{C}$

$61 \%$ (from lactone $8 \mathrm{e}$ )<smiles>[BH2-][OH+]C[C@@H]1C=C[C@H](C(Br)C(=O)N2C(=O)OC[C@H]2Br)O1</smiles>

trans-28: cis-28

$3.5: 1$ ratio

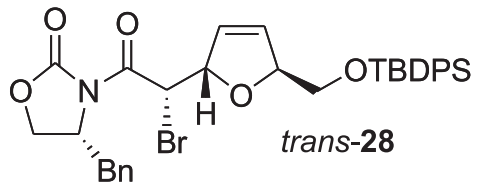

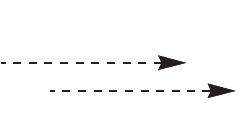<smiles>C[C@H]1C=C[C@@H]([C@H](N)C(=O)O)O1</smiles>

(-)-furanomycin 


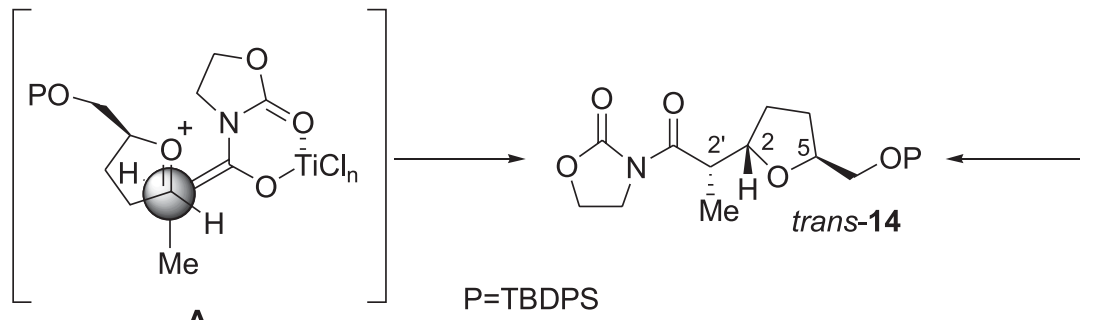

A

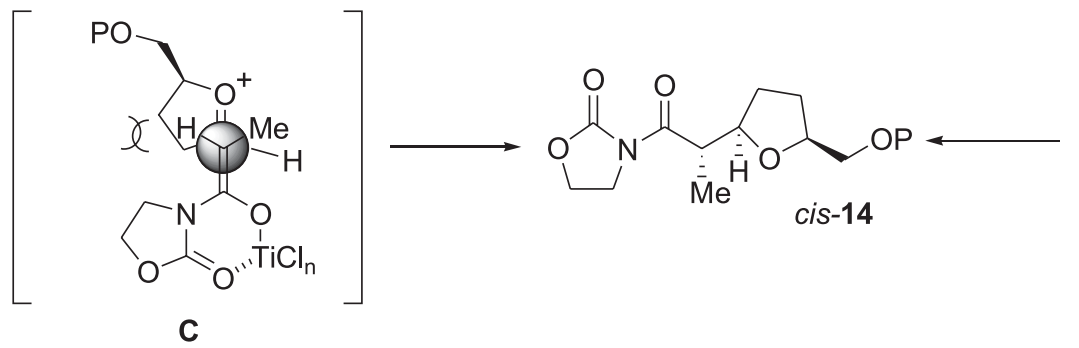

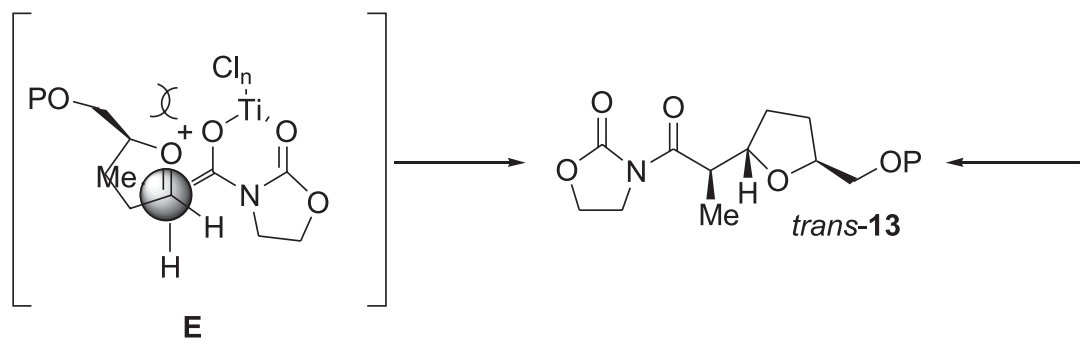

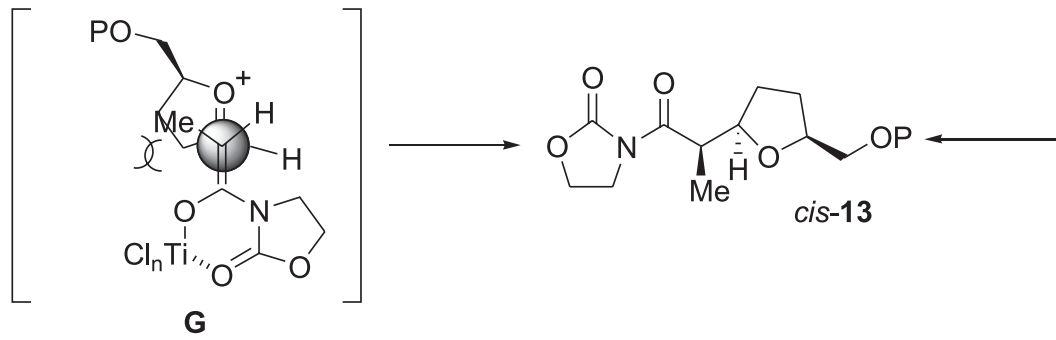

Scheme 11.

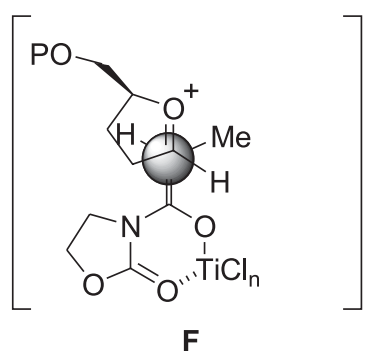

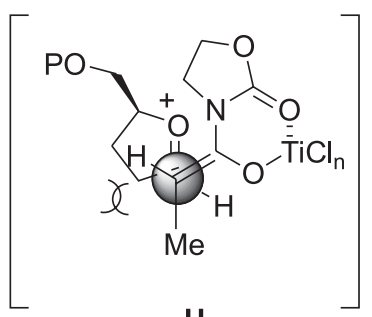
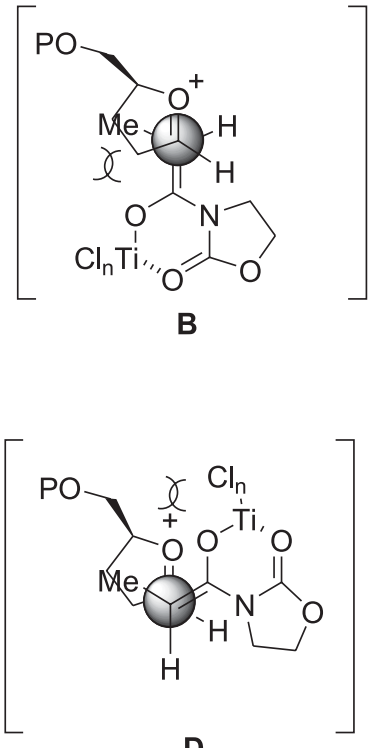

D

H of the oxocarbenium ion produced syn-18/anti-18 in good yield and without diastereoselection (1:1). However, when the titanium enolate derived from bromoacetyl oxazolidinone $(\boldsymbol{R}) \mathbf{- 1 4}$ was added to lactol $\mathbf{1 d}$, the adducts syn-17 and anti-17 were obtained in good yield and low diastereoselection (2.3:1). From the body of information described above it emerges that the oxazolidin-2-one moiety is efficiently discriminating its approach to the oxocarbenium ion: in every case, both major and minor isomers displayed the same stereochemistry at the stereogenic center arising from the nucleophile when $(R)$-4-benzyl oxazolidin-2-one was employed as chiral auxiliary revealing the preferential approach of the less hindered face of the corresponding titanium (IV) enolate.

The preferential formation of syn-17 can be rationalized either through a synclinal (I) or an antiperiplanar (J) approach while $\mathbf{K}$ and $\mathbf{L}$ approaches seem to be less favored due to the electronically disfavored interaction involving non-bonded electron pairs in the bromine and oxygen atoms of the enolate and the oxygen atom of the oxocarbenium ion (Scheme 12).

Addition of titanium (IV) enolates derived from $(\boldsymbol{R})-\mathbf{4}$ and $(\boldsymbol{R})-\mathbf{1 9}$ to lactol 1a afforded only two diastereoisomers trans-7/cis-7, 8:1 ratio and trans-23/cis-23, 7:1 ratio, 
respectively. The preferential formation of trans-7 and trans-23 can be rationalized either through a synclinal (M) or an antiperiplanar (N) approach of the titanium enolate $R e$ face to the $R e$ face of the oxocarbenium ion derived from 1a (Scheme 13). While the former arrangement minimizes the steric interaction between the methyl group of the enolate and the methylene groups of the oxocarbenium ion, the later one alleviates steric interaction between the oxazolidinone ring and the oxocarbenium ion.

The formation of the minor isomers cis-7 and cis-23 requires the antiperiplanar approach of titanium enolate $R e$ face to the sterically hindered oxocarbenium ion $\mathrm{Si}$ face (O). In this case, the synclinal approach (P) seems to be less favored due not only to steric interactions involving the $\mathrm{R}^{3}$ group in the enolate and the $-\mathrm{CH}_{2} \mathrm{OTBDPS}$ group of the oxocarbenium ion but also to the electronically disfavored interaction involving non-bonded electron pairs in closely spaced oxygen atoms (Scheme 13).

The high diastereoselection observed in the addition of bromoenolate derived from $(\boldsymbol{R}) \mathbf{- 1 4}$ to lactol $\mathbf{1 a}$ (trans-21/ cis-21 10:1) results from severe steric interaction between the bromine atom and the $-\mathrm{CH}_{2}$ OTBDPS group in the synclinal approach (P, Scheme 13) leading to cis-21, as well as to the repulsive electronic interactions in the antiperiplanar approach involving non-bonded electron pairs of the bromine atom and the oxygen atom of the oxocarbenium ion (O, Scheme 13).

Accordingly, the decrease in the diastereoselection observed for the non-substituted enolate $(\boldsymbol{R}) \mathbf{- 2 0}$ is accounted for based on the lack of a discriminating group at the nucleophilic center of $(\boldsymbol{R})-\mathbf{2 0}\left(\mathrm{R}^{3}=\mathrm{H}\right)$ and denotes the poor facial selectivity of the oxocarbenium ion.

The low diastereoselections observed in the addition of titanium enolates $(S)-\mathbf{4}$ and $(\boldsymbol{S}) \mathbf{- 1 9}$ to lactol 1a (trans-6/ cis-6 3.5:1 ratio and trans-22/cis-22 5:1 ratio, respectively) can be assigned to non-bonded electron repulsion during the synclinal approach leading to trans-6 and trans-22 (Q, Scheme 14), which is not present both in the antiperiplanar and in the synclinal approaches leading to cis-6 and cis-22 (S and T, Scheme 14).

Finally, the low diastereoselection observed in the reaction of titanium enolate $(\boldsymbol{R})-\mathbf{1 4}$ with the $\alpha$ - $\beta$-insaturated oxocarbenium ion derived from 1e $(3.5: 1)$ can be understood by the planarity of the oxocarbenium ion ring. The $-\mathrm{CH}_{2} \mathrm{OTBDPS}$ group is positioned rather remote from the reaction centre. Thus, a decrease in steric interactions led to the loss of stereoselectivity.

\section{Experimental}

\section{Materials and methods}

${ }^{1} \mathrm{H}$ NMR and ${ }^{13} \mathrm{C}$ NMR spectra were recorded in $\mathrm{CDCl}_{3}$ solution 300 and $75 \mathrm{MHz}$ respectively, using a Varian Gemini 2000 spectrometer and at 500 and $125 \mathrm{MHz}$ respectively, using a Varian Inova 500 spectrometer. Chemical shifts are expressed in ppm relative to tetramethylsilane followed by multiplicity ( $\mathrm{s}$, singlet; d, doublet; t, triplet; q, quartet; quint, quintet; $\mathrm{m}$,

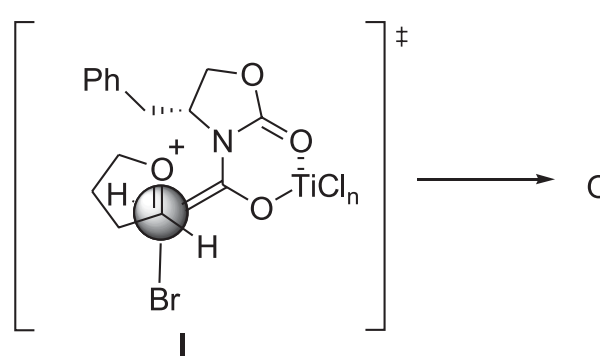

I

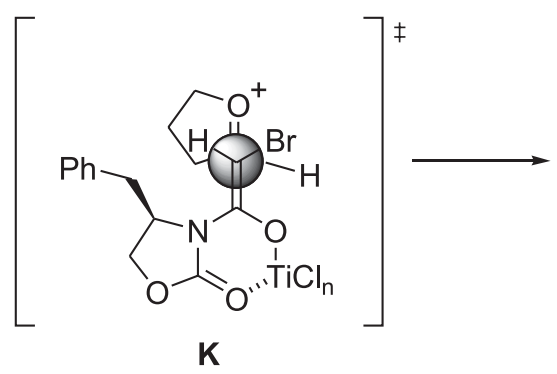<smiles>O=C1OC[C@@H](Br)[C@H]1[C@H](Br)C(=O)N1CCCO1</smiles>

syn-17
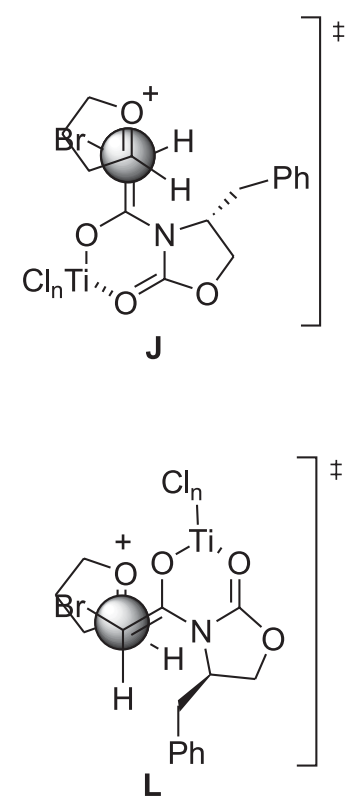

Scheme 12. 


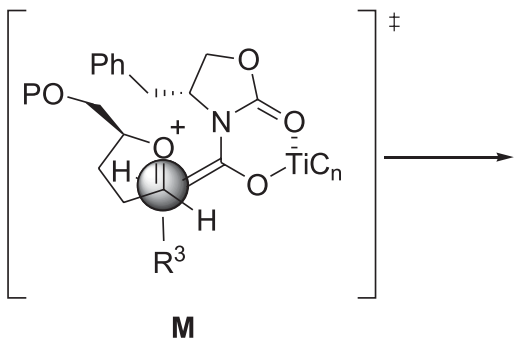

$\mathrm{P}=$ TBDPS<smiles>[R]C(C(=O)N1C(=O)OC[C@H]1Cc1ccccc1)[C@]1([R])CC[C@@H](CO)O1</smiles>

trans-23, $\mathrm{R}^{3}=\mathrm{Ph}$

trans-24, $\mathrm{R}^{3}=\mathrm{H}$

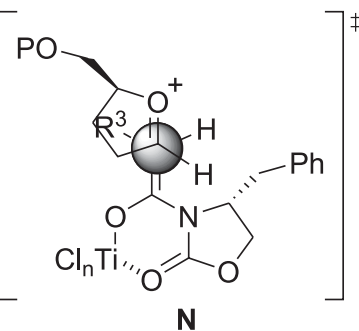

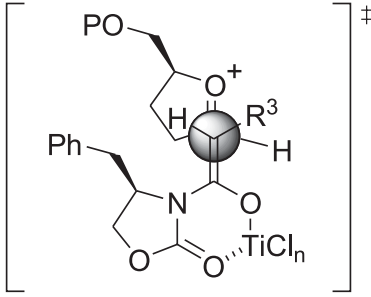

0

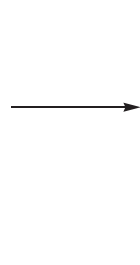
$\underbrace{\mathrm{N}}_{\mathrm{Bn}}$$$
{ }^{3} \mathrm{H}^{2}
$$$$
\begin{aligned}
& \text { cis-7, } \mathrm{R}^{3}=\mathrm{Me} \\
& \text { cis-21, } \mathrm{R}^{3}=\mathrm{Br}
\end{aligned}
$$$$
\text { cis-23, } \mathrm{R}^{3}=\mathrm{Ph}
$$$$
\text { cis-24, } \mathrm{R}^{3}=\mathrm{H}
$$

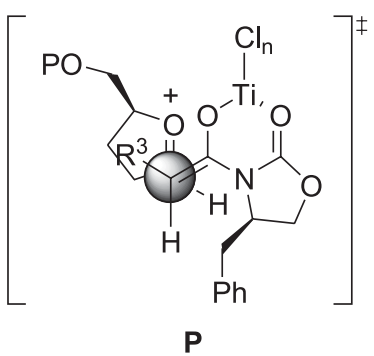

Scheme 13.

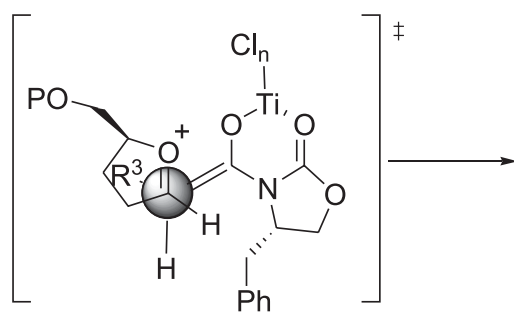

Q

$$
P=\text { TBDPS }
$$

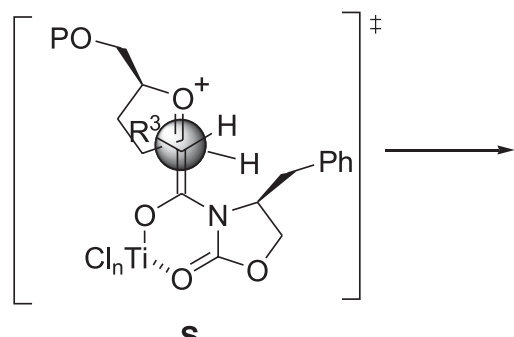

S

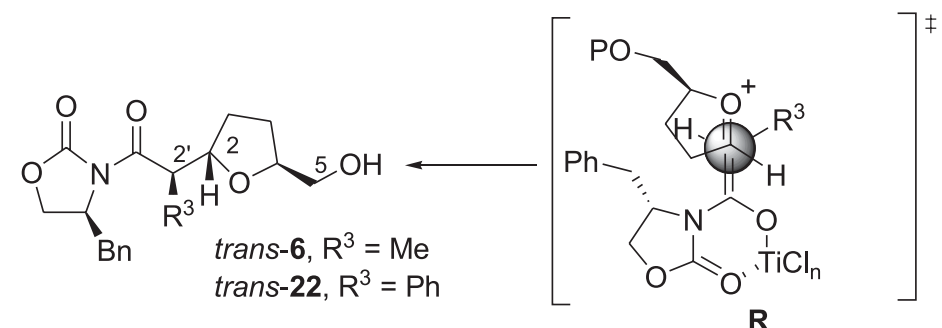
trans-22, $\mathrm{R}^{3}=\mathrm{Ph}$ $\mathbf{R}$

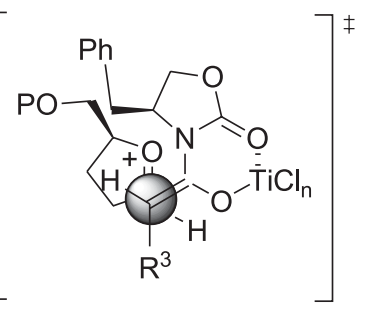

$\mathbf{T}$

Scheme 14.

multiplet), coupling constant (Hz) and number of protons. The values in parenthesis refer to the chemical shift of the minor isomer. Infrared spectra were recorded on a Nicolet Impact 410 spectrophotometer. High resolution mass spectra were obtained via electron impact $(70 \mathrm{eV})$ on a VG Autospec spectrometer. Optical rotations were measured at $24{ }^{\circ} \mathrm{C}$ in a Polamat A (Carl Zeiss). GC analyses were performed in a Hewlett-Packard 5890 series II chromatograph equipped with flame ionization detector, nitrogen as the carrier gas and capillary columns $(30 \mathrm{~m} \times$ $0.53 \mathrm{~mm}$ ) with $1 \%$ phenylmethylsilicone (HP-1) or crosslinked polyethyleneglycol (Carbowax 20M) as stationary phases. GC-MS analyses were performed on a HewlettPackard 5890 series II gas chromatograph coupled to a MSD 5970 mass detector equipped with a capillary column (Carbowax 20M, $25 \mathrm{~m} \times 0.20 \mathrm{~mm} \times 0.33 \mu$ ). Column chromatography was performed using silicagel (70-230 Mesh), except when stated otherwise, and 
reactions were monitored by TLC (plates from MachereyNagel, Germany).

Tetrahydrofuran was treated with sodium/benzophenone and distilled immediately prior to use. Dichloromethane, triethylamine and diisopropylethylamine were treated with calcium hydride and distilled immediately prior to use. $\mathrm{TiCl}_{4}$ was distilled prior to use. The remaining reagents employed were purchased from commercial suppliers and used without further purification. The reactions involving anhydrous solvents were carried out under argon atmosphere.

The achiral $N$-acyloxazolidinone derivative 9,35 the chiral ones $(R)-\mathbf{4},{ }^{35}(S)-\mathbf{4},{ }^{35}(R)-\mathbf{1 4},{ }^{36}(R)-19,{ }^{35}(S)-19,{ }^{36}$ and lactones $\mathbf{8} \mathbf{a},{ }^{37} \mathbf{8} \mathbf{b}^{38}$ and $\mathbf{8} \mathbf{e}^{33}$ were prepared according to published procedures.

\section{Experimental procedures}

(5S)-(tert-Butyl-diphenylsiloxymethyl)-tetrahydrofuran2-ol (1a)

$\mathrm{A} \mathrm{CH}_{2} \mathrm{Cl}_{2}$, solution $(5.4 \mathrm{~mL})$ of lactone $8 \mathbf{a}(0.959 \mathrm{~g}$, $2.70 \mathrm{mmol}$ ) was cooled to $-78^{\circ} \mathrm{C}$, treated with DIBAL-H $(3.24 \mathrm{~mL}, 1.0 \mathrm{~mol} / \mathrm{L}$ in toluene, $3.24 \mathrm{mmol}$ ) and stirred at $-78^{\circ} \mathrm{C}$ for $1 \mathrm{~h}$. The reaction was quenched by the addition of AcOEt $(6.5 \mathrm{~mL})$ and warmed to room temperature. Then, saturated solution of sodium potassium tartarate (6.5 mL) was added and the mixture was stirred for $2 \mathrm{~h}$. The layers were separated and the aqueous layer was extracted with $\mathrm{CH}_{2} \mathrm{Cl}_{2}(3 \times 2 \mathrm{~mL})$. The combined organic layers were washed with brine $(2 \mathrm{~mL})$, dried over $\mathrm{MgSO}_{4}$, filtered and concentrated to afford a anomeric mixture of $1 \mathrm{a}(0.953 \mathrm{~g}, 2.67 \mathrm{mmol}, 99 \%$ yield, $2: 1$ ratio) as a clear oil, which was used in the next step without further purification. IR $v_{\max } / \mathrm{cm}^{-1}: 3415,2929,2856$, 1471, 1427, 1112; ${ }^{1} \mathrm{H}$ NMR $\left(\mathrm{CDCl}_{3}, 300 \mathrm{MHz}\right) \delta 1.05$ and $1.08(\mathrm{~s}, 9 \mathrm{H}), 1.72-2.12(\mathrm{~m}, 5 \mathrm{H}), 3.55-3.90(\mathrm{~m}, 2 \mathrm{H})$, 4.10-4.40 (m, 1H), 5.26-5.60 (m, 1H), 7.20-7.45 (m, $6 \mathrm{H}), 7.66-7.70(\mathrm{~m}, 4 \mathrm{H}) ;{ }^{13} \mathrm{C} \mathrm{NMR}\left(\mathrm{CDCl}_{3}, 75 \mathrm{MHz}\right) \delta$ 19.0, 25.3 (23.6), 26.6, 31.8 (34.6), 66.0 (66.2), 78.6 (80.2), 100.8 (98.6), 127.8 (128.0), 129.8 (130.1), 135.8 (133.9), 135.9 (136.0); LRMS (EI) m/z 199 (100\%), 299 (15\%); HRMS (IE) $\mathrm{m} / z$ calc. for $\mathrm{C}_{17} \mathrm{H}_{19} \mathrm{O}_{3} \mathrm{Si}\left[\mathrm{M}-\mathrm{C}_{4} \mathrm{H}_{9}\right]^{+}$ 299.11035 , found 299.11038 .

General procedure for the addition of titanium (IV) enolates derived from 9, (R)-4, (S)-4, (R)-14, (R)-19, (S)-19 to lactols 1a-e

To a solution of $\mathrm{TiCl}_{4}(1.1 \mathrm{mmol})$ in $\mathrm{CH}_{2} \mathrm{Cl}_{2}(2.5 \mathrm{~mL})$ at $-23{ }^{\circ} \mathrm{C}$ was added a solution of oxazolidinone $9,(\boldsymbol{R})-\mathbf{4}$, $(S)-4,(R)-14,(R)-19$ and $(S)-19(1.0 \mathrm{mmol})$ in $\mathrm{CH}_{2} \mathrm{Cl}_{2}$ $(2.0 \mathrm{~mL})$ followed by the addition of diisopropylethylamine
$(1.1 \mathrm{mmol})$ after $5 \mathrm{~min}$. The reaction mixture was stirred at $-23^{\circ} \mathrm{C}$ for $1 \mathrm{~h}$ and then a solution of lactol 1a-e (1.1 mmol) in $\mathrm{CH}_{2} \mathrm{Cl}_{2}(2.5 \mathrm{~mL})$ was added dropwise. The reaction mixture was stirred at $-23{ }^{\circ} \mathrm{C}$ for $1 \mathrm{~h}$, and then quenched with satd. aq. $\mathrm{NH}_{4} \mathrm{Cl}(4 \mathrm{~mL})$. The aqueous phase was extracted with $\mathrm{CH}_{2} \mathrm{Cl}_{2}(3 \times 3 \mathrm{~mL})$, the combined organic phase was dried over $\mathrm{MgSO}_{4}$ and the solvent was removed under reduced pressure. The crude product was taken up in $\mathrm{CH}_{3} \mathrm{CN}(10 \mathrm{~mL})$ and aq. $\mathrm{HF} 40 \%$ was added dropwise until total deprotection (TLC control). Then the reaction mixture was quenched with satd. aq. $\mathrm{NaHCO}_{3}(5 \mathrm{~mL})$. The aqueous phase was extracted with $\mathrm{Et}_{2} \mathrm{O}(3 \times 3 \mathrm{~mL})$, the combined organic phase was dried over $\mathrm{MgSO}_{4}$ and the solvent was removed under reduced pressure.

3-\{(2'S)-2-[(2S,5S)-5-(tert-Butyldiphenylsiloxy-methyl)tetrahydro-2-furanyl]-propanoyl\}-1,3-oxazo-lan-2-one (trans-14)

The product was purified by chromatography on silica gel (20\% ethyl acetate-hexane) to afford a 4:4:1:1 mixture of trans-13:trans-14: cis-13: cis-14 (61\% yield). The isomers were separated by flash chromatography on silica gel $(8 \%$ ethyl acetate-hexane). Data for trans-14: colorless oil; $[\alpha]_{\mathrm{D}}=+16.6\left(c 1.54, \mathrm{CH}_{2} \mathrm{Cl}_{2}\right) ; \mathrm{IR} v_{\max } / \mathrm{cm}^{-1}: 1699,1780$; ${ }^{1} \mathrm{H}$ NMR $\left(500 \mathrm{MHz}, \mathrm{CDCl}_{3}\right) \delta 0.96(\mathrm{~s}, 9 \mathrm{H}), 1.04$ (d, J 6.8 $\mathrm{Hz}, 3 \mathrm{H}), 1.53-1.63(\mathrm{~m}, 1 \mathrm{H}), 1.68-1.75(\mathrm{~m}, 1 \mathrm{H}), 1.93-1.98$ (m, 1H), 2.00-2.05 (m, 1H), 3.49 (dd, J 5.1, $10.5 \mathrm{~Hz}, 1 \mathrm{H})$, 3.54 (dd, $J 5.1,10.5 \mathrm{~Hz}, 1 \mathrm{H}), 3.88$ (dq, $J 6.8,9.3 \mathrm{~Hz}, 1 \mathrm{H}$ ), 3.89-4.00 (m, 2H), 4.06 (quint, $J 6.0 \mathrm{~Hz}, 1 \mathrm{H}$ ), 4.12 (dt, $J$ 6.3, 9.3 Hz, 1H), 4.18-4.29 (m, 2H), 7.18-7.35 (m, 6H), 7.58-7.62 (m, 4H); ${ }^{13} \mathrm{C}$ NMR (125 MHz, $\left.\mathrm{CDCl}_{3}\right) \delta 13.9$, 19.2, 26.7, 27.9, 29.9, 42.5, 42.7, 61.7, 66.4, 79.6, 81.5, 127.6, 129.5, 133.6, 135.6, 153.4, 175.8; LRMS (EI) $m / z 199$ (100\%), 424 (33\%); HRMS (EI) $m / z$ calc. for $\mathrm{C}_{27} \mathrm{H}_{35} \mathrm{NO}_{5} \mathrm{Si}\left[\mathrm{M}-\mathrm{C}_{4} \mathrm{H}_{9}\right]^{+} 424.15803$, found 424.15821 .

3-\{(2'R)-2-[(2S,5S)-5-(tert-Butyldiphenylsilo-xymethyl)tetrahydro-2-furanyl]-propanoyl\}-1,3-oxa-zolan-2-one (trans-13)

Colorless oil; $[\alpha]_{\mathrm{D}}=-6.5\left(c 1.30, \mathrm{CH}_{2} \mathrm{Cl}_{2}\right) ; \mathrm{IR} v_{\max } / \mathrm{cm}^{-1}$ : 1699, 1778; ${ }^{1} \mathrm{H}$ NMR (500 MHz, $\left.\mathrm{CDCl}_{3}\right) \delta 1.05(\mathrm{~s}, 9 \mathrm{H})$, $1.27(\mathrm{~d}, J 6.8 \mathrm{~Hz}, 3 \mathrm{H}), 1.62-1.70(\mathrm{~m}, 1 \mathrm{H}), 1.83-1.92(\mathrm{~m}$, $1 \mathrm{H}), 1.94-2.03(\mathrm{~m}, 1 \mathrm{H}), 2.05-2.11(\mathrm{~m}, 1 \mathrm{H}), 3.65(\mathrm{~d}, J 4.7$ $\mathrm{Hz}, 2 \mathrm{H}), 3.92$ (quint, $J 6.8 \mathrm{~Hz}, 1 \mathrm{H}), 3.94-4.02(\mathrm{~m}, 2 \mathrm{H})$, 4.09-4.14 (m, 1H), 4.21-4.26 (m, 1H), 4.29-4.38 (m, 2H), 7.36-7.41 (m, 6H), 7.67-7.70 (m, 4H); ${ }^{13} \mathrm{C}$ NMR (125 $\left.\mathrm{MHz}, \mathrm{CDCl}_{3}\right) \delta 13.2,19.0,26.6,27.6,29.7,41.9,42.6$, 61.7, 66.3, 79.5, 80.3, 127.8, 129.7, 133.8, 135.8, 153.5, 175.8; LRMS (EI) m/z 199 (100\%), 424 (60\%); HRMS (EI) $m / z$ calc. for $\mathrm{C}_{27} \mathrm{H}_{35} \mathrm{NO}_{5} \mathrm{Si}\left[\mathrm{M}-\mathrm{C}_{4} \mathrm{H}_{9}\right]^{+} 424.15803$, found 424.15864 . 
(4R)-4-Benzyl-3-\{(2'S)-2-[(2S,5S)-5-hydroxy-methyltetrahydro-2-furanyl]-propanoyl\}-1,3-oxazolan-2-one (trans-7)

The product was purified by chromatography on silica gel (50\% ethyl acetate-hexane) to afford a 8:1 mixture of trans-7:cis-7 (58\% yield). The trans-7 isomer was separated by flash chromatography on silica gel (30\% ethyl acetatehexane). Data for trans-7: White solid; $\mathrm{mp} 151.5-152.5^{\circ} \mathrm{C}$; $[\alpha]_{\mathrm{D}}=-50.3\left(c 1.10, \mathrm{CH}_{2} \mathrm{Cl}_{2}\right) ; \mathrm{IR} \mathrm{v}_{\max } / \mathrm{cm}^{-1}: 3467,1693$, 1776; ${ }^{1} \mathrm{H} \mathrm{NMR}\left(300 \mathrm{MHz}, \mathrm{CDCl}_{3}\right) \delta 1.13(\mathrm{~d}, J 6.8 \mathrm{~Hz}, 3 \mathrm{H})$, 1.70-1.82 (m, 2H), 1.95-2.10 (m, 2H), 2.10-2.18 (m, 1H), $2.84(\mathrm{dd}, J 9.2,13.6 \mathrm{~Hz}, 1 \mathrm{H}), 3.26(\mathrm{dd}, J 3.3,13.6 \mathrm{~Hz}, 1 \mathrm{H})$, 3.49 (dd, J 5.5, $11.4 \mathrm{~Hz}, 1 \mathrm{H}), 3.66(\mathrm{dd}, J 3.3,11.4 \mathrm{~Hz}, 1 \mathrm{H})$, 4.04 (dq, J 6.8, 9.3 Hz, 1H), 4.13-4.23 (m, 3H), 4.28-4.33 $(\mathrm{m}, 1 \mathrm{H}), 4.69-4.75(\mathrm{~m}, 1 \mathrm{H}), 7.22-7.36(\mathrm{~m}, 5 \mathrm{H}) ;{ }^{13} \mathrm{C} \mathrm{NMR}$ $\left(75 \mathrm{MHz}, \mathrm{CDCl}_{3}\right) \delta 13.7,27.1,29.9,37.5,42.7,55.2,64.7$, 65.7, 79.4, 81.6, 127.3, 128.9, 129.6, 135.4, 153.4, 176.0; LRMS (EI) $m / z 101$ (100\%), 333 (43\%); HRMS (EI) $\mathrm{m} / z$ calc. for $\mathrm{C}_{18} \mathrm{H}_{23} \mathrm{NO}_{5}[\mathrm{M}]^{+} 333.15762$, found 333.15714.

(4S)-4-Benzyl-3-\{(2'R)-2-[(2S,5S)-5-hydroxy-methyltetrahydro-2-furanyl]-propanoyl\}-1,3-oxazolan-2-one (trans-6)

The product was purified by chromatography on silica gel (50\% ethyl acetate-hexane) to afford a 3.5:1 mixture of trans-6:cis-6 (55\% yield). The isomers were separated by flash chromatography on silica gel (30\% ethyl acetatehexane). Data for trans-6: White solid; $\mathrm{mp} 91.4-93.2^{\circ} \mathrm{C}$; $[\alpha]_{\mathrm{D}}=+57.3\left(c 0.52, \mathrm{CH}_{2} \mathrm{Cl}_{2}\right) ; \mathrm{IR} v_{\max } / \mathrm{cm}^{-1}: 3467,1693$, 1776; ${ }^{1} \mathrm{H}$ NMR $\left(300 \mathrm{MHz}, \mathrm{CDCl}_{3}\right) \delta 1.27(\mathrm{~d}, J 6.8 \mathrm{~Hz}$, $3 \mathrm{H}), 1.66-1.85(\mathrm{~m}, 2 \mathrm{H}), 1.94-2.08(\mathrm{~m}, 1 \mathrm{H}), 2.09-2.18(\mathrm{~m}$, 1H), 2.33 (br s, 1H), 2.74 (dd, J 9.5, 13.2 Hz, 1H), 3.28 (dd, $J$ 2.9, $13.2 \mathrm{~Hz}, 1 \mathrm{H}), 3.51$ (dd, J 6.2, $11.7 \mathrm{~Hz}, 1 \mathrm{H})$, 3.67 (dd, $J 3.7,11.7 \mathrm{~Hz}, 1 \mathrm{H}$ ), 3.98 (quint, $J 6.8 \mathrm{~Hz}, 1 \mathrm{H}$ ), 4.08-4.23 (m, 3H), 4.27 (q, J $6.8 \mathrm{~Hz}, 1 \mathrm{H}), 4.66-4.73$ (m, $1 \mathrm{H}), 7.22-7.37(\mathrm{~m}, 5 \mathrm{H}) ;{ }^{13} \mathrm{C} \mathrm{NMR}\left(75 \mathrm{MHz}, \mathrm{CDCl}_{3}\right) \delta 13.3$, 27.2, 29.8, 37.8, 41.9, 55.2, 64.8, 65.9, 79.7, 80.3, 127.4, 128.9, 129.5, 135.3, 153.3, 175.4; LRMS (EI) $\mathrm{m} / z .302$ (100\%), 333 (10\%); HRMS (EI) $m / z$ calc. for $\mathrm{C}_{18} \mathrm{H}_{23} \mathrm{NO}_{5}$ $[\mathrm{M}]^{+}$333.15762, found 333.15752.

(4S)-4-Benzyl-3-\{(2'R)-2-[(2R,5S)-5-hydroxy-methyltetrahydro-2-furanyl]-propanoyl\}-1,3-oxazolan-2-one (cis-6)

White solid; $\mathrm{mp} 105.2-106.3^{\circ} \mathrm{C} ;[\alpha]_{\mathrm{D}}=+62.3(\mathrm{c} 0.41$, $\left.\mathrm{CH}_{2} \mathrm{Cl}_{2}\right) ; \mathrm{IR} v_{\max } / \mathrm{cm}^{-1}: 3467,1693,1776 ;{ }^{1} \mathrm{H}$ NMR (500 $\left.\mathrm{MHz}, \mathrm{CDCl}_{3}\right) \delta 1.17(\mathrm{~d}, J 6.8 \mathrm{~Hz}, 3 \mathrm{H}), 1.71-1.79(\mathrm{~m}, 1 \mathrm{H})$, 1.83 (br s, 1H), 1.90-2.03 (m, 2H), 2.08-2.15 (m, 1H), 2.84 (dd, $J 9.0,13.4 \mathrm{~Hz}, 1 \mathrm{H}), 3.27$ (dd, $J 3.4,13.4 \mathrm{~Hz}, 1 \mathrm{H}), 3.47$ (dd, J 3.9, $12.0 \mathrm{~Hz}, 1 \mathrm{H}), 3.73$ (dd, J 2.9, $12.0 \mathrm{~Hz}, 1 \mathrm{H}), 4.02$ $(\mathrm{dq}, J 6.8,9.3 \mathrm{~Hz}, 1 \mathrm{H}), 4.08-4.15(\mathrm{~m}, 2 \mathrm{H}), 4.16-4.22(\mathrm{~m}$, 2H), 4.70-4.74 (m, 1H), 7.26-7.35 (m, 5H); ${ }^{13} \mathrm{C}$ NMR (75
$\left.\mathrm{MHz}, \mathrm{CDCl}_{3}\right) \delta 14.0,27.0,30.5,37.4,42.6,55.6,65.1,65.7$, 79.9, 83.0, 127.4, 129.0, 129.5, 135.4, 154.0, 176.1; LRMS (EI) $m / z 302(100 \%), 333(08 \%)$; HRMS (EI) $m / z$ calc. for $\mathrm{C}_{18} \mathrm{H}_{23} \mathrm{NO}_{5}[\mathrm{M}]^{+}$333.15762, found 333.15775.

(4R)-4-Benzyl-3-\{(2'S)-2'-bromo-2-[(2S,5S)-5-hydroxymethyltetrahydro-2-furanyl]-acetyl\}-1,3-oxa-zolan-2-one (trans-21)

The adduct was deprotected using HF/pyridine. To a solution of adduct $(1.15 \mathrm{mmol})$ in THF $(20 \mathrm{~mL})$ in a Nalgene tube was added freshly prepared buffered pyridinium hydrofluoride $(19.0 \mathrm{~mL})$ (stock solution prepared from $2.0 \mathrm{~g}$ of Aldrich pyridinium hydrofluoride, $4.0 \mathrm{~mL}$ of pyridine and $16 \mathrm{~mL}$ of THF). After $3 \mathrm{~h}$ at room temperature, satd. aq. $\mathrm{NaHCO}_{3}(20 \mathrm{~mL})$ was added. The layers were separated, the aqueous layer was extracted with $\mathrm{Et}_{2} \mathrm{O}(3 \times 5 \mathrm{~mL})$, the combined organic layers were washed with brine $(7 \mathrm{~mL})$, dried over $\mathrm{MgSO}_{4}$ and concentrated under reduced pressure. The product was purified by chromatography on silica gel (40\% ethyl acetate-hexane) to afford a 10:1 mixture of trans-21:cis-21 (57\% yield). The trans-21 isomer was separated by flash chromatography on silica gel (20\% ethyl acetate-hexane). Data for trans-21: White solid; mp $150.1-150.7^{\circ} \mathrm{C} ;[\alpha]_{\mathrm{D}}=-121.5$ ( c 1.05, $\left.\mathrm{CH}_{2} \mathrm{Cl}_{2}\right)$; IR $v_{\max } / \mathrm{cm}^{-1}: 3448,1778,1603 ;{ }^{1} \mathrm{H}$ NMR (300 $\left.\mathrm{MHz}, \mathrm{CDCl}_{3}\right) \delta$ 1.79-1.89 (m, 2H), 2.01-2.11 (m, 2H), 2.30-2.38 (m, 1H), 2.93 (dd, J 8.4, $13.6 \mathrm{~Hz}, 1 \mathrm{H}), 3.24$ (dd, $J$ 2.9, $13.6 \mathrm{~Hz}, 1 \mathrm{H}), 3.52$ (dd, J 5.5, $11.7 \mathrm{~Hz}, 1 \mathrm{H}), 3.69$ (dd, J 3.3, 11.7 Hz, 1H), 4.14-4.32 (m, 3H), 4.70-4.77 (m, 2H), $5.61(\mathrm{~d}, J 9,5 \mathrm{~Hz}, 1 \mathrm{H}), 7.23-7.36(\mathrm{~m}, 5 \mathrm{H}) ;{ }^{13} \mathrm{C} \mathrm{NMR}$ $\left(75 \mathrm{MHz}, \mathrm{CDCl}_{3}\right) \delta 26.9,30.2,37.4,43.7,55.5,64.6,66.1$, 79.7, 80.9, 127.6, 129.1, 129.6, 134.8, 152.9, 168.6; LRMS (EI) $\mathrm{m} / \mathrm{z} .91$ (100\%), 397 (06\%); HRMS (EI) $\mathrm{m} / z$ calc. for $\mathrm{C}_{17} \mathrm{H}_{20} \mathrm{BrNO}_{5}[\mathrm{M}]^{+}$397.05248, found 397.05240.

(4R)-4-Benzyl-3-\{(2'S)-2'-bromo-2-[(2S)-tetra-hydro-2furanyl]-acetyl\}-1,3-oxazolan-2-one (syn-17)

The product was purified by chromatography on silica gel (20\% ethyl acetate-hexane) to afford a 2.3:1 mixture of syn-17:anti-17 (54\% yield). The syn-17 isomer was separated by flash chromatography on silica gel $(15 \%$ ethyl acetate-hexane) as a white solid. Data for syn-17: mp 112.5-114.5 ${ }^{\circ} \mathrm{C} ;[\alpha]_{\mathrm{D}}=-87.6\left(c 2.0, \mathrm{CHCl}_{3}\right) ; \mathrm{IR} v_{\max }{ }^{\prime}$ $\mathrm{cm}^{-1}: 1780,1705 ;{ }^{1} \mathrm{H} \mathrm{NMR}\left(500 \mathrm{MHz}, \mathrm{CDCl}_{3}\right) \delta 1.85-1.99$ (m, 3H), 2.17-2.23 (m, 1H), $2.84(\mathrm{dd}, J 8.9,13.7 \mathrm{~Hz}, 1 \mathrm{H})$, 3.19 (dd, J 3.1, $13.7 \mathrm{~Hz}, 1 \mathrm{H}), 3.82-3.90$ (m, 2H), 4.13 (dd, $J 9.0,2.6 \mathrm{~Hz}, 1 \mathrm{H}), 4.20$ (t, $J 9.0 \mathrm{~Hz}, 1 \mathrm{H}), 4.57$ (ddd, $J 9.7$, 7.2, 4.9 Hz, 1H), 4.64-4.69 (m, 1H), 5.48 (d, J 9.7 Hz, 1H), 7.17-7.27 (m, 5H); ${ }^{13} \mathrm{C}$ NMR (125 $\left.\mathrm{MHz}, \mathrm{CDCl}_{3}\right) \delta$ 25.7, 30.1, 37.4, 43.8, 55.6, 66.1, 69.6, 79.3, 127.4, 128.9, 129.6, 134.8, 152.7, 168.5; LRMS (EI) $\mathrm{m} / \mathrm{z} 367$ (2\%); 
HRMS (EI) $\mathrm{m} / z$ calc. for $\mathrm{C}_{16} \mathrm{H}_{18} \mathrm{BrNO}_{4}[\mathrm{M}]^{+} 367.04192$, found 367.04192 .

(4R)-4-Benzyl-3-\{(2'S)-2-[(2S/R)-tetrahydro-2-furanyl]propanoyl\}-1,3-oxazolan-2-one (syn-18:anti-18)

The product was purified by chromatography on silica gel (15\% ethyl acetate-hexane) to afford a 1:1 mixture of syn-18:anti-18 (67\% yield) as a colorless oil. IR $v_{\max } / \mathrm{cm}^{-1}$ : 1777, 1694; ${ }^{1} \mathrm{H}$ NMR $\left(300 \mathrm{MHz}, \mathrm{CDCl}_{3}\right) \delta 1.14$ and $1.26(\mathrm{~d}$, $J 7.0 \mathrm{~Hz}, 3 \mathrm{H}$ ), 1.60-2.15 (m, 4H), 2.75 and 2.83 (dd, $J$ 9.5, $13.4 \mathrm{~Hz}, 1 \mathrm{H}), 3.30$ (dd, $J 14.4 ; 2.6 \mathrm{~Hz}, 1 \mathrm{H}), 3.75-4.04(\mathrm{~m}, 3 \mathrm{H})$, 4.11-4.25 (m, 3H), 4.65-4.77 (m, 1H), 7.20-7.36 (m, 5H); ${ }^{13} \mathrm{C}$ NMR $\left(75 \mathrm{MHz}, \mathrm{CDCl}_{3}\right) \delta 12.8$ and 13.9, 25.6 and 25.6, 29.2 and 29.5, 37.4 and 37.8, 41.9 and 42.8, 55.1 and 55.2, 65.6 and 65.9, 68.1 and 68.3, 79.9 and 81.2, 127.2 and 127.3, 128.8 and $128.9,129.5$ and $129.6,135.3$ and $135.5,153.4,175.5$ and 176.1; LRMS (EI) $m / z 303$ (100\%); HRMS (EI) $\mathrm{m} / z$ calc. for $\mathrm{C}_{17} \mathrm{H}_{21} \mathrm{NO}_{4}[\mathrm{M}]^{+}$303.14706, found 303.14693.

(4S)-4-Benzyl-3-\{(2'R)-2'-phenyl-2-[(2S,5S)-5-hydroxymethyltetrahydro-2-furanyl]-acetyl\}-1,3-oxazo-lan-2-one (trans-22)

The product was purified by chromatography on silica gel (30\% ethyl acetate-hexane) to afford a 5:1 mixture of trans-22:cis-22 (58\% yield). The trans-22 isomer was separated by flash chromatography on silica gel (15\% ethyl acetate-hexane). Data for trans-22: Colorless solid; $\mathrm{mp}$ 42.0-43.7 ${ }^{\circ} \mathrm{C} ;[\alpha]_{\mathrm{D}}=+110.2\left(\mathrm{c} 2.47, \mathrm{CH}_{2} \mathrm{Cl}_{2}\right) ; \mathrm{IR} v_{\max } / \mathrm{cm}^{-1}$ : $3469,1778,1693 ;{ }^{1} \mathrm{H}$ NMR $\left(500 \mathrm{MHz}, \mathrm{CDCl}_{3}\right) \delta$ 1.70-1.85 (m, 3H), 1.94-2.02 (m, 1H), 2.21-2.26 (m, 1H), 2.78 (dd, $J$ 9.6, $13.4 \mathrm{~Hz}, 1 \mathrm{H}), 3.33$ (dd, $J 3.3,13.4 \mathrm{~Hz}, 1 \mathrm{H}), 3.42$ (dd, $J$ $5.8,11.8 \mathrm{~Hz}, 1 \mathrm{H}), 3.58$ (dd, J 3.3, $11.8 \mathrm{~Hz}, 1 \mathrm{H}$ ), 4.01-4.11 $(\mathrm{m}, 3 \mathrm{H}), 4.57-4.61(\mathrm{~m}, 1 \mathrm{H}), 4.68(\mathrm{dt}, J 6.8,8.2 \mathrm{~Hz}, 1 \mathrm{H})$, 5.17 (d, J 8.2 Hz, 1H), 7.22-7.46 (m, 10H); 13C NMR (125 $\left.\mathrm{MHz}, \mathrm{CDCl}_{3}\right) \delta 27.0,30.8,37.9,53.4,55.5,64.6,65.8$, 79.5, 81.0, 127.4, 127.6, 128.4, 128.9, 129.4 (2C), 135.1, 135.9, 152.9, 172.2; LRMS (EI) $\mathrm{m} / z 295$ (100\%); 364 (06\%); HRMS (EI) $m / z$ calc. for $\mathrm{C}_{23} \mathrm{H}_{25} \mathrm{NO}_{5}\left[\mathrm{M}-\mathrm{CH}_{2} \mathrm{OH}\right]^{+}$ 364.15488; found 364.15477.

(4R)-4-Benzyl-3-\{(2'S)-2'-phenyl-2-[(2S,5S)-5-hydroxymethyltetrahydro-2-furanyl]-acetyl\}-1,3-oxazo-lan-2-one (trans-23)

The product was purified by chromatography on silica gel (30\% ethyl acetate-hexane) to afford a 7:1 mixture of trans-23:cis-23 (56\% yield). The trans-23 isomer was separated by flash chromatography on silica gel (15\% ethyl acetate-hexane). Data for trans-23 Colorless solid; mp 47.5-48.9 ${ }^{\circ} \mathrm{C} ;[\alpha]_{\mathrm{D}}=+60.8\left(\mathrm{c} 0.21, \mathrm{CH}_{2} \mathrm{Cl}_{2}\right) ; \mathrm{IR} v_{\max } / \mathrm{cm}^{-1}$ : 3469, 1778, 1693; ${ }^{1} \mathrm{H}$ NMR $\left(500 \mathrm{MHz}, \mathrm{CDCl}_{3}\right) \delta 1.60-1.66$ (m, 2H), 1.72-1.76 (m, 1H), 1.86-1.94 (m, 2H), 2.96 (dd, $J$
8.8, $13.5 \mathrm{~Hz}, 1 \mathrm{H}), 3.28$ (dd, J 3.2, $13.5 \mathrm{~Hz}, 1 \mathrm{H}), 3.55$ (dd, $J$ $4.7,11.8 \mathrm{~Hz}, 1 \mathrm{H}), 3.77$ (dd, J 3.0, $11.8 \mathrm{~Hz}, 1 \mathrm{H}), 4.11$ (dd, $J$ $7.3,10.0 \mathrm{~Hz}, 1 \mathrm{H}), 4.14$ (dd, J 2.1, $10.0 \mathrm{~Hz}, 1 \mathrm{H}), 4.16-4.21$ $(\mathrm{m}, 1 \mathrm{H}), 4.62-4.67(\mathrm{~m}, 1 \mathrm{H}), 4.74$ (ddd, $J$ 6.6, 7.5, 10.0 $\mathrm{Hz}, 1 \mathrm{H}), 5.20$ (d, J $10.0 \mathrm{~Hz}, 1 \mathrm{H}), 7.26-7.47(\mathrm{~m}, 10 \mathrm{H}) ;{ }^{13} \mathrm{C}$ NMR (125 MHz, $\left.\mathrm{CDCl}_{3}\right) \delta 26.8,29.9,37.5,54.3,55.7$, $65.2,65.6,80.5,82.2,127.4,128.0,128.7,128.9,129.2$, 129.4, 135.1, 135.3, 153.5, 173.0; LRMS (EI) $\mathrm{m} / \mathrm{z} 295$ (100\%); $364(06 \%)$; HRMS (EI) $m / z$ calc. for $\mathrm{C}_{23} \mathrm{H}_{25} \mathrm{NO}_{5}$ $\left[\mathrm{M}-\mathrm{CH}_{2} \mathrm{OH}\right]^{+}$364.15488; found 364.15446.

(4R)-4-Benzyl-3-\{(2'S)-2'-bromo-2-[(5S)-5-tert-butyldiphenylsiloxymethyl)-dihydro-2-furanyl]-acety\}-1,3oxazolan-2-one (trans-28)

The product was purified by chromatography on silica gel (20\% ethyl acetate-hexane) to afford a 3.5:1 mixture of trans-28:cis-28 (61\% yield) as a colorless oil. Data for trans-28: IR $v_{\max } / \mathrm{cm}^{-1}: 1782,1705,1647,1589 ;{ }^{1} \mathrm{H}$ NMR $\left(500 \mathrm{MHz}, \mathrm{CDCl}_{3}\right) \delta 0.95(\mathrm{~s}, 9 \mathrm{H}), 2.80(\mathrm{dd}, J 13.5 ; 9.0 \mathrm{~Hz}$, 1H), 3.17 (dd, $J 13.5 ; 2.9 \mathrm{~Hz}, 1 \mathrm{H}), 3.60$ (dd, $J$ 10.5; 5.1 $\mathrm{Hz}, 1 \mathrm{H}), 3.65$ (dd, $J$ 10.5; $4.6 \mathrm{~Hz}, 1 \mathrm{H}), 4.10-4.24$ (m, 2H), 4.61-4.68 (m, 1H), 4.98-4.99 (m, 1H), 5.36-5.40 (m, 1H), $5.47(\mathrm{~d}, J 9.5 \mathrm{~Hz}, 1 \mathrm{H}), 5.97(\mathrm{~d}, J 6.1 \mathrm{~Hz}, 1 \mathrm{H}), 6.12(\mathrm{~d}, J 6.3$ $\mathrm{Hz}, 1 \mathrm{H}), 7.10-7.24$ (m, 5H), 7.26-7.38 (m, 6H), 7.56-7.65 $(\mathrm{m}, 4 \mathrm{H}) ;{ }^{13} \mathrm{C} \mathrm{NMR}\left(75 \mathrm{MHz}, \mathrm{CDCl}_{3}\right) \delta 19.2,26.7,37.4$, 44.0, 55.5, 66.1 (2C), 86.2, 88.0, 127.4, 127.6, 128.3, 128.9, 129.6 (2C), 131.1, 133.4, 134.7, 135.6, 152.6, 168.0.

(4R)-4-Benzyl-3-\{2-[(2S,5S)-5-hydroxymethyl-te-trahydro2-furanyl]-acetyl\}-1,3-oxazolan-2-one (trans-24)

To a solution of trans $-\mathbf{2 1}(0.398 \mathrm{~g}, 1.00 \mathrm{mmol})$ in DME $(2.0 \mathrm{~mL})$ was added a catalitic amount $(0.100 \mathrm{mmol})$ of AIBN. The reaction was stirred for $1 \mathrm{~h}$ at $80^{\circ} \mathrm{C}$ and $\mathrm{Bu}_{3} \mathrm{SnH}$ $(0.323 \mathrm{~mL}, 1.20 \mathrm{mmol})$ was added. After $1 \mathrm{~h}$ at $80^{\circ} \mathrm{C}$ it was cooled at room temperature and was added satd. aq. $\mathrm{NH}_{4} \mathrm{Cl}(2 \mathrm{~mL})$ and $10 \% \mathrm{KF}$ aq. (2 mL). The mixture was stirred $1 \mathrm{~h}$ and $5 \mathrm{~mL}$ of $\mathrm{Et}_{2} \mathrm{O}$ was added. The layers were separated, the aqueous phase was extracted with $\mathrm{Et}_{2} \mathrm{O}(3 \times$ $3 \mathrm{~mL}$ ), the combined organic phase was dried over $\mathrm{MgSO}_{4}$ and the solvent was removed under reduced pressure. The crude product was diluted with AcOEt $(5 \mathrm{~mL})$, filtered and the solvent was removed under reduced pressure. Silica gel chromatography (50\% AcOEt in hexanes, v/v) of the crude product afforded trans-24 $(0.267 \mathrm{~g}, 0.84 \mathrm{mmol})$ in $84 \%$ yield. The product was purified by chromatography on silica gel (60\% ethyl acetate-hexane) as a colorless oil. $[\alpha]_{\mathrm{D}}=-41.2\left(c 1.65, \mathrm{CH}_{2} \mathrm{Cl}_{2}\right) ; \mathrm{IR} v_{\max } / \mathrm{cm}^{-1}: 3444,1778$, 1699; ${ }^{1} \mathrm{H}$ NMR $\left(300 \mathrm{MHz}, \mathrm{CDCl}_{3}\right) \delta 1.55-1.76(\mathrm{~m}, 3 \mathrm{H})$, 1.85-2.04 (m, 1H), 2.09-2.18 (m, 1H), $2.73(\mathrm{dd}, J 9.2,13.5$ $\mathrm{Hz}, 1 \mathrm{H}), 2.96$ (dd, J 5.1, $16.5 \mathrm{~Hz}, 1 \mathrm{H}), 3.24$ (dd, J 2.9, 13.5 $\mathrm{Hz}, 1 \mathrm{H}), 3.30$ (dd, $J 8.1,16.5 \mathrm{~Hz}, 1 \mathrm{H}), 3.45$ (dd, $J$ 5.9, 
$11.7 \mathrm{~Hz}, 1 \mathrm{H}), 3.62(\mathrm{dd}, J 3.3,11.7 \mathrm{~Hz}, 1 \mathrm{H}), 4.08-4.18$ (m, $3 \mathrm{H}), 4.45-4.53(\mathrm{~m}, 1 \mathrm{H}), 4.59-4.67(\mathrm{~m}, 1 \mathrm{H}), 7.13-7.29(\mathrm{~m}$, $5 \mathrm{H}) ;{ }^{13} \mathrm{C} \mathrm{NMR}\left(75 \mathrm{MHz}, \mathrm{CDCl}_{3}\right) \delta 27.1,32.0,37.8,41.5$, 55.1, 64.8, 66.1, 75.1, 79.2, 127.3, 128.9, 129.5, 135.1, 153.5, 170.9; LRMS (EI) $\mathrm{m} / z 288$ (100\%), 319 (06\%); HRMS (EI) $m / z$ calc. for $\mathrm{C}_{17} \mathrm{H}_{21} \mathrm{NO}_{5}[\mathrm{M}]^{+} 319.14197$, found 319.14191 .

(4R)-4-Benzyl-3-\{(2'R)-2'-azide-2-[(2S,5S)-5-hy-droxymethyltetrahydro-2-furanyl]-acetyl\}-1,3-oxazo-lan-2-one (27)

To a solution of trans-21 (0.0470 g, $0.118 \mathrm{mmol})$ in DMF $(0.5 \mathrm{~mL})$ at room temperature, was added $\mathrm{NaN}_{3}$ $(0.0150 \mathrm{~g}, 0.236 \mathrm{mmol})$. The reaction was stirred for $24 \mathrm{~h}$ at room temperature and DMF was removed under reduced pressure. $\mathrm{CH}_{2} \mathrm{Cl}_{2}(10 \mathrm{~mL})$ was added and the mixture was washed with brine $(2 \mathrm{~mL})$, dried over $\mathrm{MgSO}_{4}$, filtered and concentrated. Silica gel chromatography (70\% ethyl acetate-hexane) of the crude product afforded $27(0.0310 \mathrm{~g}$, $0.0861 \mathrm{mmol})$ in $73 \%$ yield. $[\alpha]_{\mathrm{D}}=-42.5\left(c 1.2 ; \mathrm{CH}_{2} \mathrm{Cl}_{2}\right)$; IR $v_{\max } / \mathrm{cm}^{-1}: 3335,2112,1778,1705 ;{ }^{1} \mathrm{H}$ NMR $(500 \mathrm{MHz}$, $\left.\mathrm{CDCl}_{3}\right) \delta 1.68(\mathrm{sl}, 1 \mathrm{H}), 1.78-1.87(\mathrm{~m}, 1 \mathrm{H}), 2.03-2.13(\mathrm{~m}$, 2H), 2.20-2.25 (m, 1H), 2.84 (dd, $J 13.4 ; 9.8 \mathrm{~Hz}, 1 \mathrm{H}), 3.38$ (dd, $J 13.4 ; 3.2 \mathrm{~Hz}, 1 \mathrm{H}), 3.52$ (dd, $J 12.0 ; 5.4 \mathrm{~Hz}, 1 \mathrm{H})$, 3.73 (dd, $J 12.0 ; 3.2 \mathrm{~Hz}, 1 \mathrm{H}), 4.24-4.32$ (m, 3H), 4.52 (dt, $J$ 6.8; $2.9 \mathrm{~Hz}, 1 \mathrm{H}), 4.71-4.76(\mathrm{~m}, 1 \mathrm{H}), 4.84(\mathrm{~d}, J 2.9 \mathrm{~Hz}$, $1 \mathrm{H}), 7.18-7.36(\mathrm{~m}, 5 \mathrm{H}) ;{ }^{13} \mathrm{C} \mathrm{NMR}\left(125 \mathrm{MHz}, \mathrm{CDCl}_{3}\right) \delta$ 27.3, 29.5, 37.4, 55.7, 62.7, 64.5, 66.8, 79.5, 80.9, 127.5, $128.9,129.4,134.7,153.1,169.4$.

(5S)-5-(tert-Butyl-diphenylsiloxymehyl)-dihy-dro-furan2-ol (1e)

A $\mathrm{CH}_{2} \mathrm{Cl}_{2}$ solution $(6 \mathrm{~mL})$ of lactone $8 \mathrm{e}(1.06 \mathrm{~g}$, $3.01 \mathrm{mmol}$ ) was cooled to $-78^{\circ} \mathrm{C}$, treated with DIBAL-H (6.01 mL, 1.0 $\mathrm{M}$ in toluene, $6.01 \mathrm{mmol}$ ) and stirred at $-78{ }^{\circ} \mathrm{C}$ for $1 \mathrm{~h}$. The reaction was quenched by the addition of AcOEt (12 mL) and warmed to room temperature. Then, saturated solution of sodium potassium tartarate $(12 \mathrm{~mL})$ was added and the mixture was stirred for $2 \mathrm{~h}$. The layers were separated and the aqueous layer was extracted with $\mathrm{CH}_{2} \mathrm{Cl}_{2}(3 \times 5 \mathrm{~mL})$. The combined organic layers were washed with brine ( $4 \mathrm{~mL})$, dried over $\mathrm{MgSO}_{4}$, filtered and concentrated to afford $1 \mathrm{e}(0.960 \mathrm{~g}, 2.71 \mathrm{mmol}, 90 \%$ yield $)$ as a clear oil, which was used in the next step without further purification. IR $v_{\max } / \mathrm{cm}^{-1}: 3419,1589$.

General procedure for the reduction of $N$-acyloxazolidinones

To a suspension of $\mathrm{LiBH}_{4}(5.0 \mathrm{mmol})$ in THF $(10.0 \mathrm{~mL})$ at $0{ }^{\circ} \mathrm{C}$ under argon, was added dropwise a solution of acyloxazolidinone $(1.0 \mathrm{mmol})$ in THF $(2.0 \mathrm{~mL})$ and
$\mathrm{MeOH}$ (4.0 mmol). The cooling bath was removed and the reaction was let to stir $3 \mathrm{~h}$ at room temperature. The reaction was then quenched with $1 \mathrm{M}$ aqueous solution of sodium potassium tartarate $(5 \mathrm{~mL})$ and stirred until both layers were clear. The mixture was poured into ether and water, the layers were separated and the aqueous phase was extracted with $\mathrm{Et}_{2} \mathrm{O}(3 \times 1 \mathrm{~mL})$. The combined organic layers were dried over $\mathrm{MgSO}_{4}$ and concentrated under reduced pressure.

(2'S)-2-[(2S,5S)-5-Hydroxymethyltetrahydro-2-furanyl]propan-1-ol (15)

The crude product from trans-6 was purified by flash chromatography on silica gel $\left(10 \% \mathrm{CHCl}_{3}-\mathrm{MeOH}\right)$ to afford $\mathbf{1 5}$ as a colorless oil in $87 \%$ yield and the oxazolidinone $(S)-4$ was recovered in $88 \%$ yield. $[\alpha]_{D}=$ $+22.4\left(c 0.38, \mathrm{CH}_{2} \mathrm{Cl}_{2}\right)$; IR v $\mathrm{Iax}_{\max } / \mathrm{cm}^{-1}: 3363,1036 ;{ }^{1} \mathrm{H} \mathrm{NMR}$ $\left(300 \mathrm{MHz}, \mathrm{CDCl}_{3}\right) \delta 0.92(\mathrm{~d}, J 7.0 \mathrm{~Hz}, 3 \mathrm{H}), 1.63-1.83(\mathrm{~m}$, $2 \mathrm{H}), 1.88-2.02(\mathrm{~m}, 3 \mathrm{H}), 2.55$ (br s, $2 \mathrm{H}), 3.49$ (dd, J 6.2, $11.7 \mathrm{~Hz}, 1 \mathrm{H}), 3.57$ (dd, J 4.8, $11.0 \mathrm{~Hz}, 1 \mathrm{H}), 3.64$ (dd, $J$ $2.9,11.7 \mathrm{~Hz}, 1 \mathrm{H}), 3.68$ (dd, J 7.3, $11.0 \mathrm{~Hz}, 1 \mathrm{H}), 4.07-4.16$ (m, 2H); $\left.{ }^{13} \mathrm{C} \mathrm{NMR} \mathrm{(75} \mathrm{MHz,} \mathrm{CDCl}_{3}\right) \delta 11.8,27.3,28.1$, 38.3, 64.8, 65.9, 79.8, 82.1; LRMS (EI) $\mathrm{m} / z .101$ (100\%), $129(75 \%)$; HRMS (EI) $m / z$ calc. for $\mathrm{C}_{8} \mathrm{H}_{16} \mathrm{O}_{3}\left[\mathrm{M}-\mathrm{CH}_{3} \mathrm{O}\right]^{+}$ 129.09155, found 129.09137 .

(2'R)-2-[(2S, 5S)-5-Hydroxymethyltetrahydro-2-furanyl]propan-1-ol (16)

The crude product trans-7 was purified by flash chromatography on silica gel $\left(10 \% \mathrm{CHCl}_{3}-\mathrm{MeOH}\right)$ to afford $\mathbf{1 6}$ as a colorless oil in $88 \%$ yield and the oxazolidinone $(\boldsymbol{R})-4$ was recovered in $73 \%$ yield. $[\alpha]_{D}=+12.2(c 0.35$, $\mathrm{CH}_{2} \mathrm{Cl}_{2}$ ); IR $v_{\max } / \mathrm{cm}^{-1}: 3363,1036 ;{ }^{1} \mathrm{H}$ NMR $(500 \mathrm{MHz}$, $\left.\mathrm{CDCl}_{3}\right) \delta 0.82(\mathrm{~d}, J 6.8 \mathrm{~Hz}, 3 \mathrm{H}), 1.61-1.79(\mathrm{~m}, 3 \mathrm{H})$, 1.94-1.99 (m, 1H), 2.10-2.15 (m, 1H), 2.40 (br s, 2H), 3.51 (dd, J 5.9, $11.7 \mathrm{~Hz}, 1 \mathrm{H}), 3.62-3.69(\mathrm{~m}, 3 \mathrm{H}), 3.82$ (dt, J 5.6, $8.8 \mathrm{~Hz}, 1 \mathrm{H}), 4.13-4.18(\mathrm{~m}, 1 \mathrm{H}) ;{ }^{13} \mathrm{C} \mathrm{NMR}\left(75 \mathrm{MHz}, \mathrm{CDCl}_{3}\right)$ $\delta$ 13.2, 26.8, 31.5, 40.6, 64.7, 68.3, 79.8, 85.3; LRMS (EI) $\mathrm{m} / \mathrm{z}, 57$ (100\%), 129 (76\%); HRMS (EI) $\mathrm{m} / \mathrm{z}$ calc. for $\mathrm{C}_{8} \mathrm{H}_{16} \mathrm{O}_{3}\left[\mathrm{M}-\mathrm{CH}_{3} \mathrm{O}\right]^{+}$129.09155, found 129.09182 .

(2'S)-2-[(2R,5S)-5-Hydroxymethyltetrahydro-2-furanyl]propan-1-ol (25)

The crude product cis-6 was purified by flash chromatography on silica gel $\left(10 \% \mathrm{CHCl}_{3}-\mathrm{MeOH}\right)$ to afford 25 as a colorless oil in $88 \%$ yield and the oxazolidinone $(S)-4$ was recovered in $86 \%$ yield. $[\alpha]_{\mathrm{D}}=-21.3\left(c 0.20, \mathrm{CH}_{2} \mathrm{Cl}_{2}\right) ; \mathrm{IR} v_{\max } / \mathrm{cm}^{-1}: 3384,1036 ;{ }^{1} \mathrm{H}$ NMR $\left(500 \mathrm{MHz}, \mathrm{CDCl}_{3}\right) \delta 0.84(\mathrm{~d}, J 7.1 \mathrm{~Hz}, 3 \mathrm{H}), 1.60-1.70$ (m, 1H), 1.71-1.82 (m, 2H), 1.85-1.94 (m, 1H), 2.00-2.09 (m, 1H), 2.45 (br s, 2H), 3.50 (dd, J 5.1, $11.7 \mathrm{~Hz}, 1 \mathrm{H})$, 
3.58-3.67 (m, 2H), 3.70-3.79 (m, 2H), 4.03-4.10 (m, 1H); ${ }^{13} \mathrm{C} \mathrm{NMR}\left(75 \mathrm{MHz}, \mathrm{CDCl}_{3}\right) \delta 13.6,26.1,30.7,40.6,64.9$, 68.3, 80.0, 86.0; LRMS (EI) $\mathrm{m} / z 57$ (100\%), 129 (71\%); HRMS (EI) $m / z$ calc. for $\mathrm{C}_{8} \mathrm{H}_{16} \mathrm{O}_{3}\left[\mathrm{M}-\mathrm{CH}_{3} \mathrm{O}\right]^{+} 129.09155$, found 129.09181 .

\section{2-[(2S,5S)-5-Hydroxymethyltetrahydro-2-fura-nyl]-ethan- 1-ol (26)}

The crude product trans-24 was purified by flash chromatography on silica gel $\left(10 \% \mathrm{CHCl}_{3}-\mathrm{MeOH}\right)$ to afford $(2 S, 5 S)-16$ as a colorless oil in $89 \%$ yield and the oxazolidinone $(\boldsymbol{R})-\mathbf{4}$ was recovered in $85 \%$ yield. $[\alpha]_{D}=-21.3\left(c 0.20, \mathrm{CH}_{2} \mathrm{Cl}_{2}\right) ; \mathrm{IR} v_{\max } / \mathrm{cm}^{-1}: 3363,1053$; ${ }^{1} \mathrm{H}$ NMR $\left(300 \mathrm{MHz}, \mathrm{CDCl}_{3}\right) \delta 1.50-1.76(\mathrm{~m}, 6 \mathrm{H}), 1.88-2.06$ (m, 2H), 3.43 (dd, J 6.1, $11.4 \mathrm{~Hz}, 1 \mathrm{H}), 3.58$ (dd, J 3.3, $11.4 \mathrm{~Hz}, 1 \mathrm{H}), 3.73$ (t, $J 5.5 \mathrm{~Hz}, 2 \mathrm{H}), 4.07-4.14$ (m, 2H); ${ }^{13} \mathrm{C}$ NMR $\left(75 \mathrm{MHz}, \mathrm{CDCl}_{3}\right) \delta 27.2,32.4,37.4,61.5,64.9$, 79.2, 79.4; LRMS (EI) $\mathrm{m} / \mathrm{z} 101$ (100\%), 115 (03\%); HRMS (EI) $\mathrm{m} / z$ calc. for $\mathrm{C}_{7} \mathrm{H}_{14} \mathrm{O}_{3}\left[\mathrm{M}-\mathrm{CH}_{3} \mathrm{O}\right]^{+} 115.07590$, found 115.07421.

\section{Conclusion}

The addition of chiral titanium (IV) enolates to oxocarbenium ions derived from 5-substituted $\gamma$-lactols occurred with good diastereoselectivity in most cases. These stereoselectivities can be understood by an open transition state with the favored approach of the less hindered face of a Z-configured internally coordinated titanium enolate to the sterically more available face of oxocarbenium ion. The products generated from these substitution reactions provide access to 2,5-transdisubstituted tetrahydrofuran rings with excellent recovery of the chiral auxiliary. The diastereoisomers were readily distinguishable by ${ }^{1} \mathrm{H}$ NMR spectroscopy as the vicinal coupling constants $\left({ }^{3} J_{2,2}\right)$ for the hydrogens in the newly created stereogenic centers: $J=9.0-10.0 \mathrm{~Hz}$ and $J=6.0-8.2 \mathrm{~Hz}$ for syn and anti respectively. This methodology can be applied to synthesize polyoxygenated structures such as those embedded in biologically active natural products.

\section{Acknowledgments}

We acknowledge FAPESP for financial support and a fellowship (V.B.R.) and CNPq for a fellowship (R.A.P.).

\section{Supplementary Information}

Suplementary data are available free of charge at http://jbcs.sbq.org.br, as PDF file.

\section{References}

1. Faul, M. M.; Huff, B. E.; Chem. Rev. 2000, 100, 2407.

2. Bermejo, A.; Figadere, B.; Zafra-Polo, M.-C.; Barrachina, I.; Estornell, E.; Cortes, D.; Nat. Prod. Rep. 2005, 22, 269.

3. Keinan, E.; Sinha, A.; Yazbak, A.; Sinha, S. C.; Pure Appl. Chem. 1997, 69, 423.

4. Hoppe, R.; Scharf, H.-D.; Synthesis 1995, 1447.

5. Figadere, B.; Acc. Chem. Res. 1995, 28, 359.

6. Zeng, L.; Ye, Q.; Oberlies, N. H.; Shi, G.; Gu, Z.-M.; He, K.; McLaughlin, J. L.; Nat. Prod. Rep. 1996, 13, 275.

7. Nattrass, G. L.; Diez, E.; McLachlan, M. M.; Dixon, D. J.; Ley, S. V.; Angew. Chem. Int. Ed. 2005, 44, 580.

8. Franck, X.; Hocquemiller, R.; Figadere, B.; Chem. Commun. 2002, 160.

9. Brown, D. S.; Bruno, M.; Davenport, R. J.; Ley, S. V.; Tetrahedron 1989, 45, 4293.

10. Jalce, G.; Seck, M.; Franck, X.; Hocquemiller, R.; Figadere, B.; J. Org. Chem. 2004, 69, 3240.

11. Pilli, R. A.; Riatto, V. B.; Vencato, I.; Org. Lett. 2000, 2, 53.

12. Postema, M. H. D.; Tetrahedron 1992, 48, 8545.

13. Schmidt, R. R. In Comprehensive Organic Synthesis; Trost, B. M.; Fleming, I., eds.; Pergamon Press: Oxford, 1991; vol. 6, p. 33.

14. Wolfe, J. P.; Hay, M. B.; Tetrahedron 2007, 63, 261.

15. Reissig, H.-U.; Schmitt, A.; Synlett 1990, 40.

16. Reissig, H.-U.; Schmitt, A.; Chem. Ber. 1995, 128, 871.

17. Reissig, H.-U.; Schmitt, A.; Eur. J. Org. Chem. 2000, 3893.

18. Reissig, H.-U.; Schmitt, A.; Eur. J. Org. Chem. 2001, 1169.

19. Cherest, M.; Felkin, H.; Prudent, N.; Tetrahedron Lett. 1968, 2205.

20. Anh, N. T.; Top. Cur. Chem. 1980, 88, 145.

21. Shaw, J. T.; Woerpel, K. A.; Tetrahedron 1999, 55, 8747.

22. Larsen, C. H.; Ridgway, B. H.; Shaw, J. T.; Woerpel, K. A.; J. Am. Chem. Soc. 1999, 121, 12208.

23. Bear, T. J.; Shaw, J. T.; Woerpel, K. A.; J. Org. Chem. 2002, 67, 2056.

24. Smith, D. M.; Tran, M. B.; Woerpel, K. A.; J. Am. Chem. Soc. 2003, 125,14149

25. Woerpel, K. A.; J. Am. Chem. Soc. 2005, 127, 10879.

26. Larrosa, I.; Romea, P.; Urpi F.; Balsells, D.; Vilarrasa, J.; FontBardia, M.; Solans, X.; Org. Lett. 2002, 4, 4651.

27. Pilli, R. A.; Riatto, V. B.; Tetrahedron: Asymmetry 2000, 11, 3675.

28. Evans, D. A.; Rieger, D. L.; Bilodeau, M. T.; Urpi, F.; J. Am. Chem. Soc. 1991, 113, 1047.

29. Pilli, R. A.; Alves, C. F.; Böckelmann, M. A.; Mascarenhas, Y. P.; Nery, J. G.; Vencato, I.; Tetrahedron Lett. 1999, 40, 2891.

30. Pilli, R. A.; Böckelmann, M. A.; Alves, C. F.; J. Braz. Chem. Soc. 2001, 12, 634 . 
31. Ravid, U.; Silverstein, R. M.; Smith, L. R.; Tetrahedron 1978, $34,1449$.

32. Evans, D. A.; Sjogren, E. B.; Weber, A. E.; Conn, R. E.; Tetrahedron Lett.1987, 28, 39.

33. Chen, S. H.; Li, X.; Chuansheng, Niu; Carmichael, E.; Doyle, T. W.; J. Org. Chem. 1997, 62, 3449.

34. Zimmermann, P. J.; Lee, J. Y.; Hiobilova, I.; Endermann, R.; Habich, D.; Jager, V.; Eur. J. Org. Chem. 2005, 3450 and references therein.

35. Ager, D. J.; Allen, D. R.; Schaad, D. R.; Synthesis 1996, 1283.
36. Evans, D. A.; Weber, A. E.; J. Am. Chem. Soc. 1987, 109, 7151.

37. Hanessian, S.; Grillo, T. A.; J. Org. Chem. 1998, 63, 1049.

38. Rassu, G.; Zanardi, F.; Battistini, L.; Gaetani, E.; Casiraghi, G.; J. Med. Chem. 1997, 40, 168.

Received: August 22, 2007 Web Release Date: March 19, 2008

FAPESP helped in meeting the publication costs of this article. 


\section{Stereoselective Addition of Chiral Titanium Enolates to 5-Substituted Five-Membered Oxocarbenium Ions}

\section{Ronaldo A. Pilli ${ }^{*, a}$ and Valéria B. Riatto ${ }^{b}$}

${ }^{a}$ Instituto de Química, Universidade Estadual de Campinas, 13083-970 Campinas-SP, Brazil

${ }^{b}$ Faculdade de Saúde, Centro Universitário da Bahia, 41770-130 Salvador-BA, Brazil

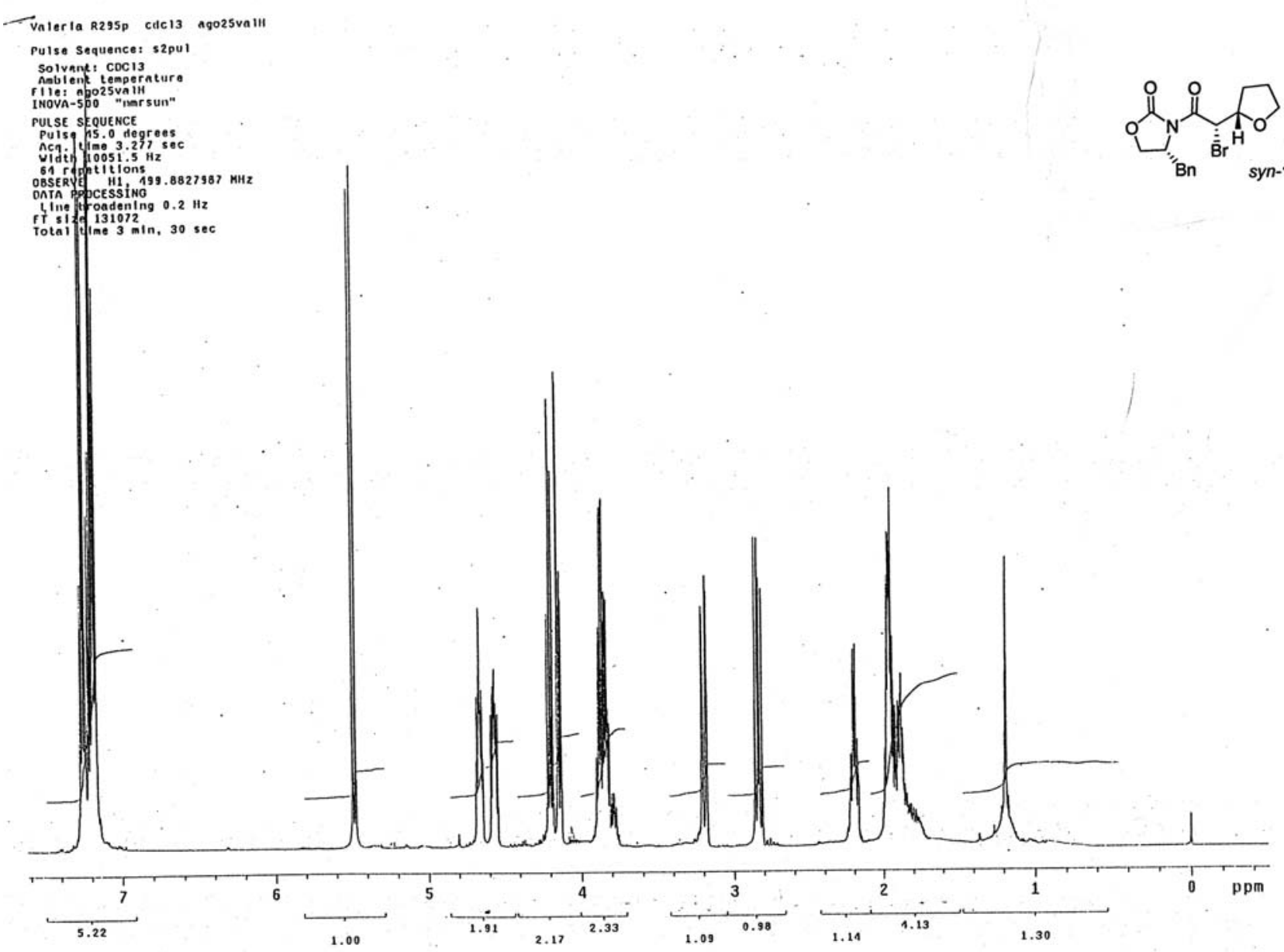

Figure S1. ${ }^{1} \mathrm{H}$ NMR spectrum of $s y n-17\left(500 \mathrm{MHz}, \mathrm{CDCl}_{3}\right)$ 


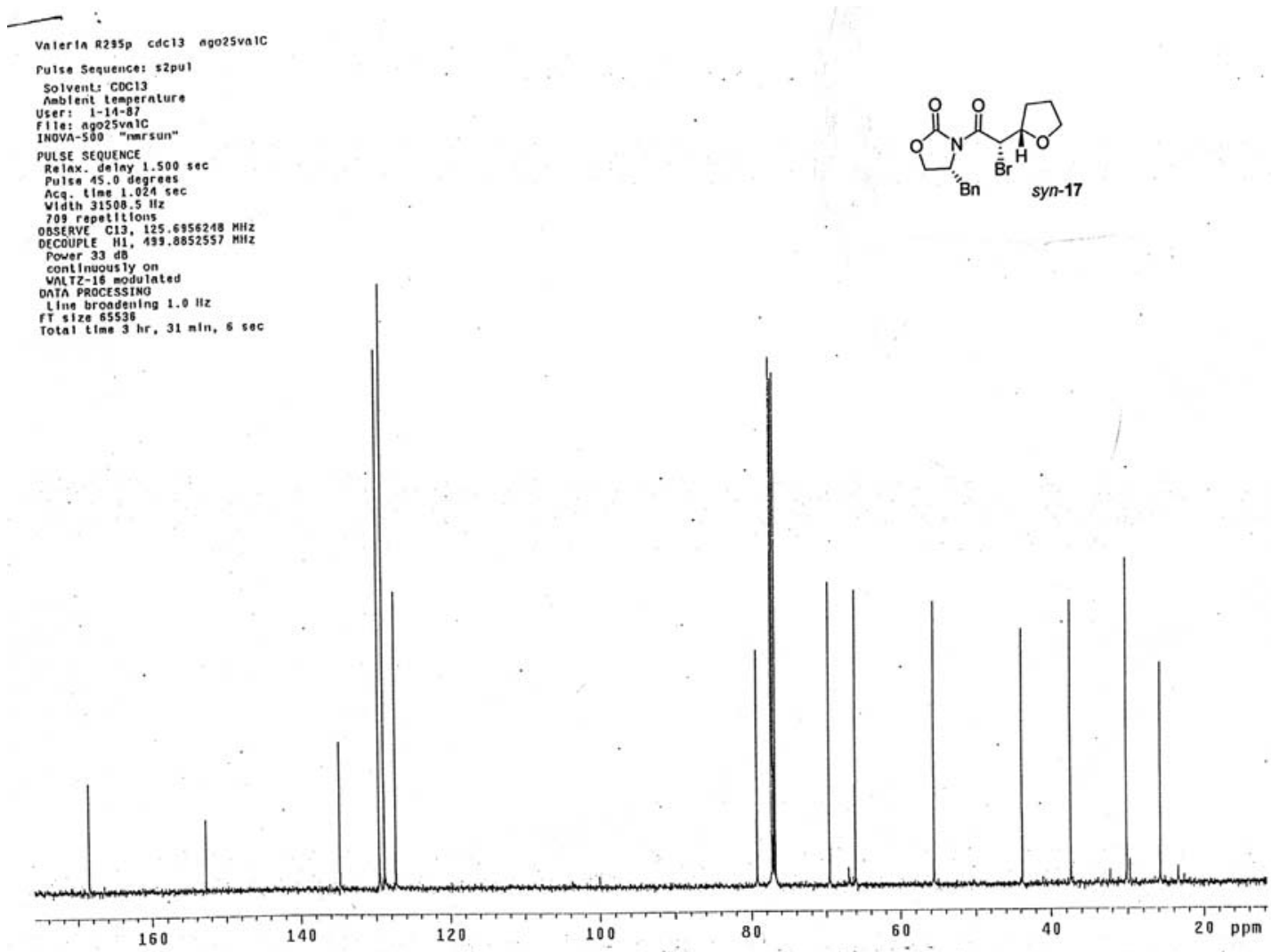

Figure S2. ${ }^{13} \mathrm{C}$ NMR spectrum of syn-17 $\left(125 \mathrm{MHz}, \mathrm{CDCl}_{3}\right)$

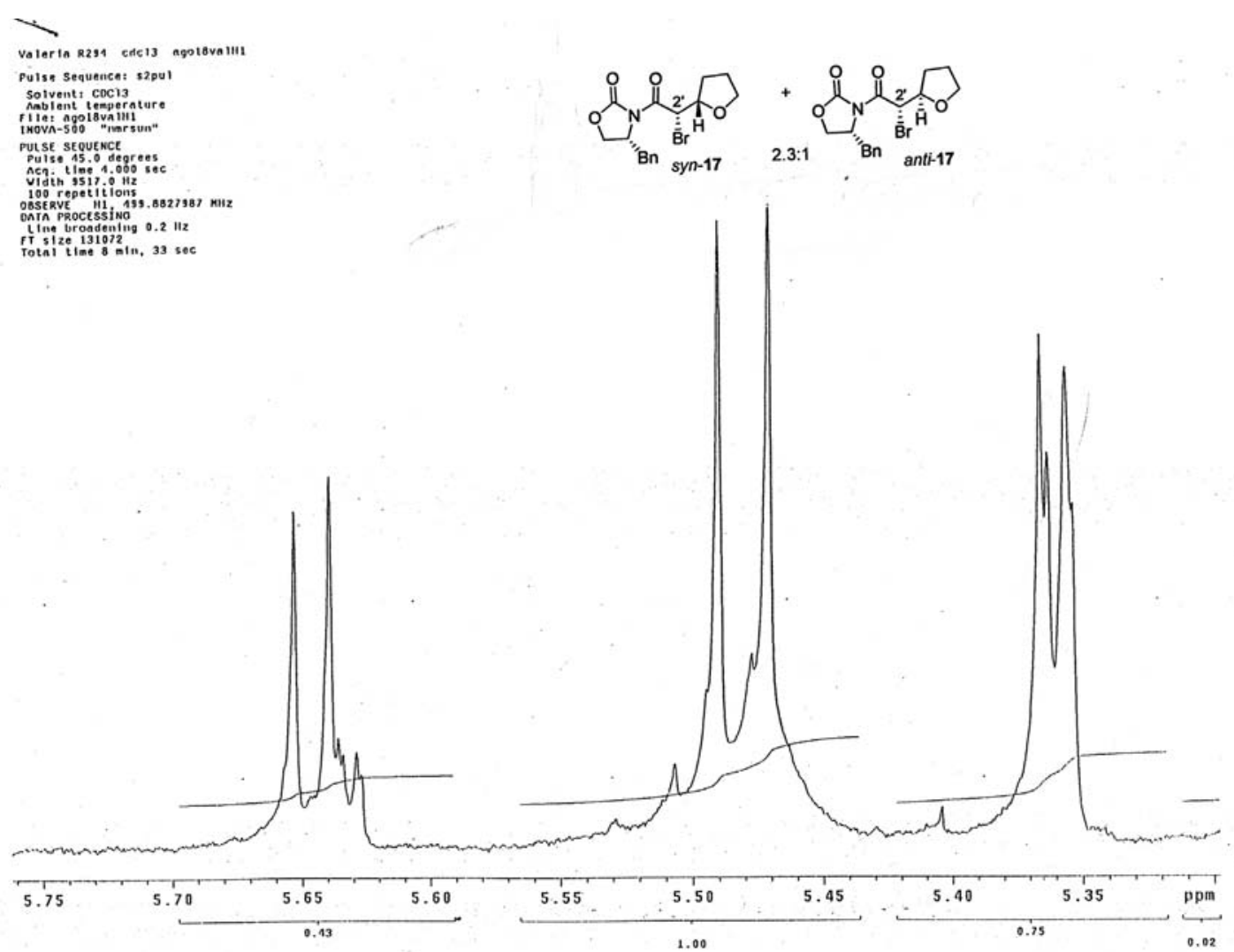

Figure S3. ${ }^{1} \mathrm{H}$ NMR spectrum of a crude mixture of syn-17/anti-17 $\left(\mathrm{CDCl}_{3}, 500 \mathrm{MHz}\right)$ syn-17: $5.48\left(\mathrm{~d}, J 9.7 \mathrm{~Hz}, \mathrm{H}_{2}\right)$ and anti-17: $5.64\left(\mathrm{~d}, J 7.0 \mathrm{~Hz}, \mathrm{H}_{2}\right)$ 


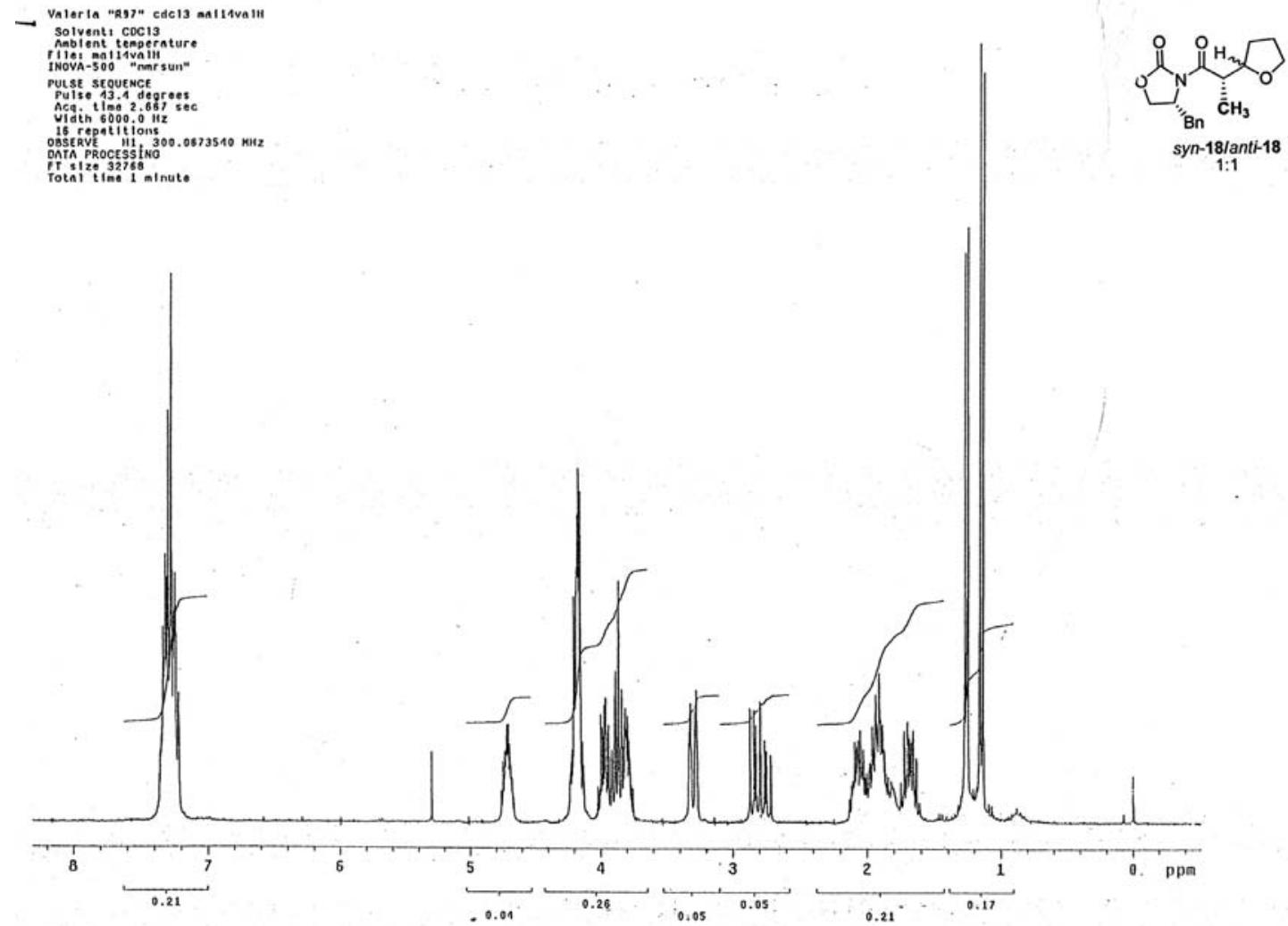

Figure S4. ${ }^{1} \mathrm{H}$ NMR spectrum of 1:1 syn-18/anti-18 mixture (300 MHz, $\left.\mathrm{CDCl}_{3}\right)$

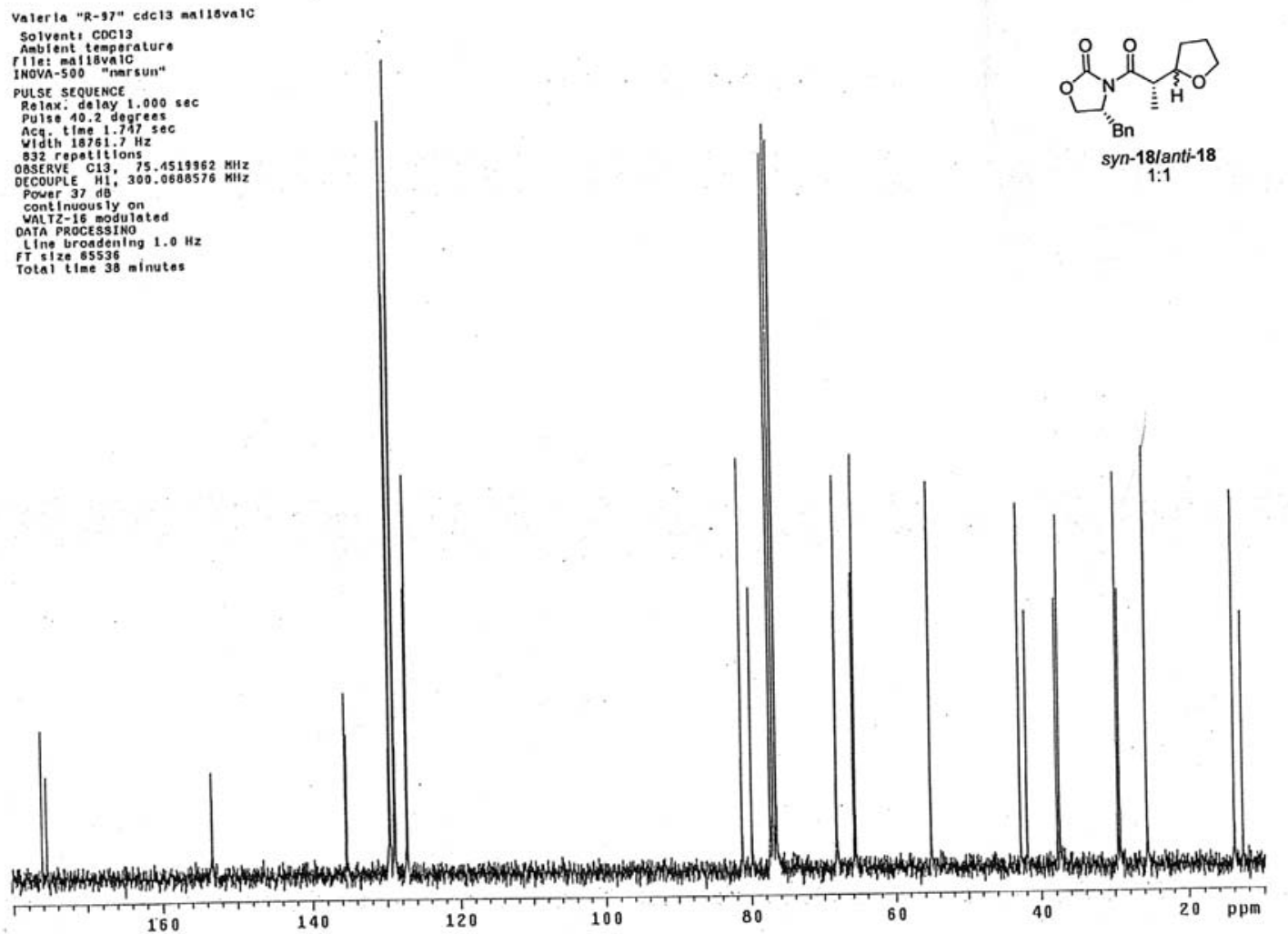

Figure S5. ${ }^{13} \mathrm{C}$ NMR spectrum of $1: 1$ syn-18/anti-18 mixture $\left(75 \mathrm{MHz}, \mathrm{CDCl}_{3}\right)$ 


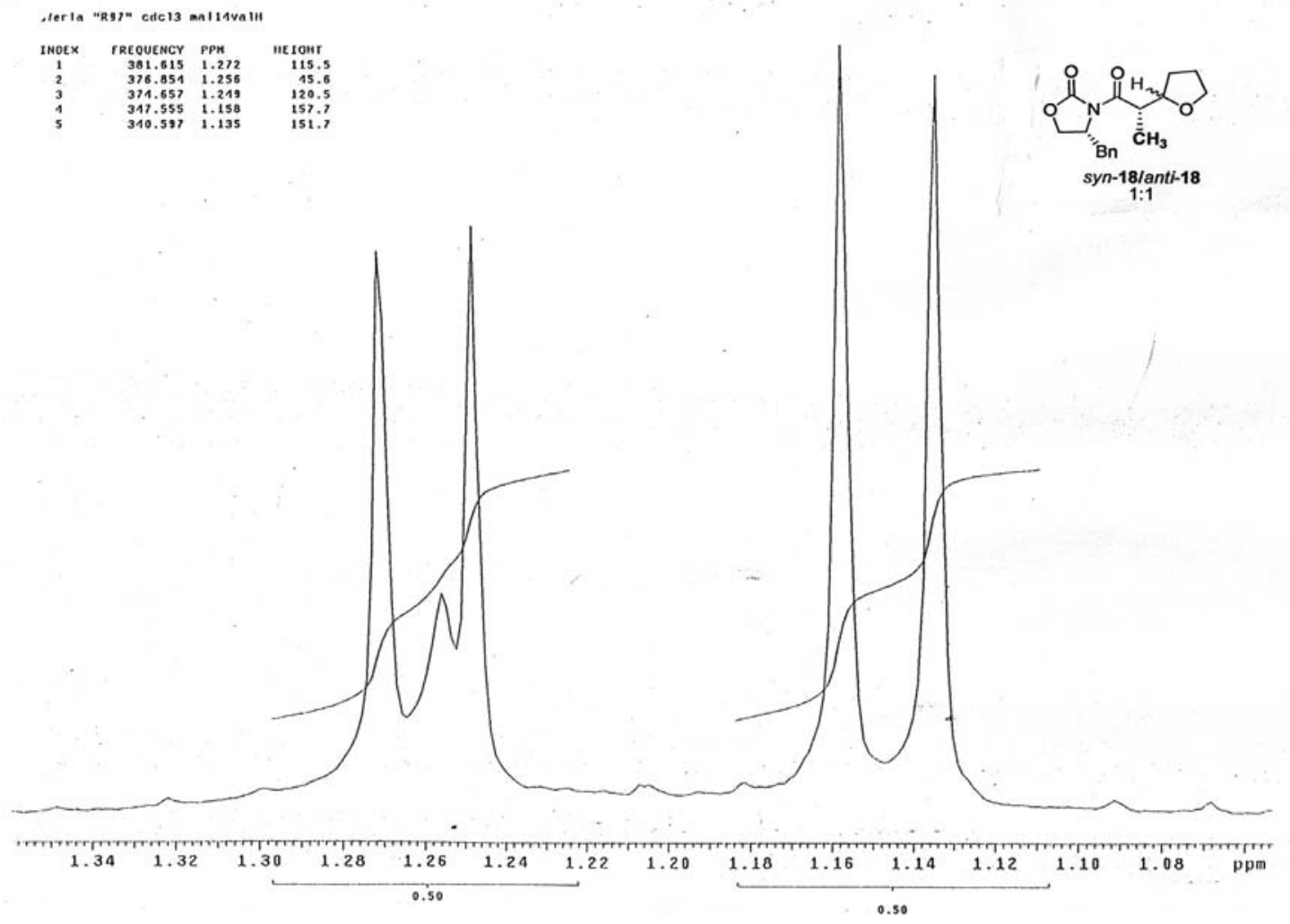

Figure S6. ${ }^{1} \mathrm{H}$ NMR spectrum of a crude mixture of syn-18/anti-18 $\left(\mathrm{CDCl}_{3}, 300 \mathrm{MHz}\right) 1.26\left(\mathrm{~d}, J 7.0 \mathrm{~Hz}, \mathrm{CH}_{3}\right)$ and $1.14\left(\mathrm{~d}, J 7.0 \mathrm{~Hz}, \mathrm{CH}_{3}\right)$

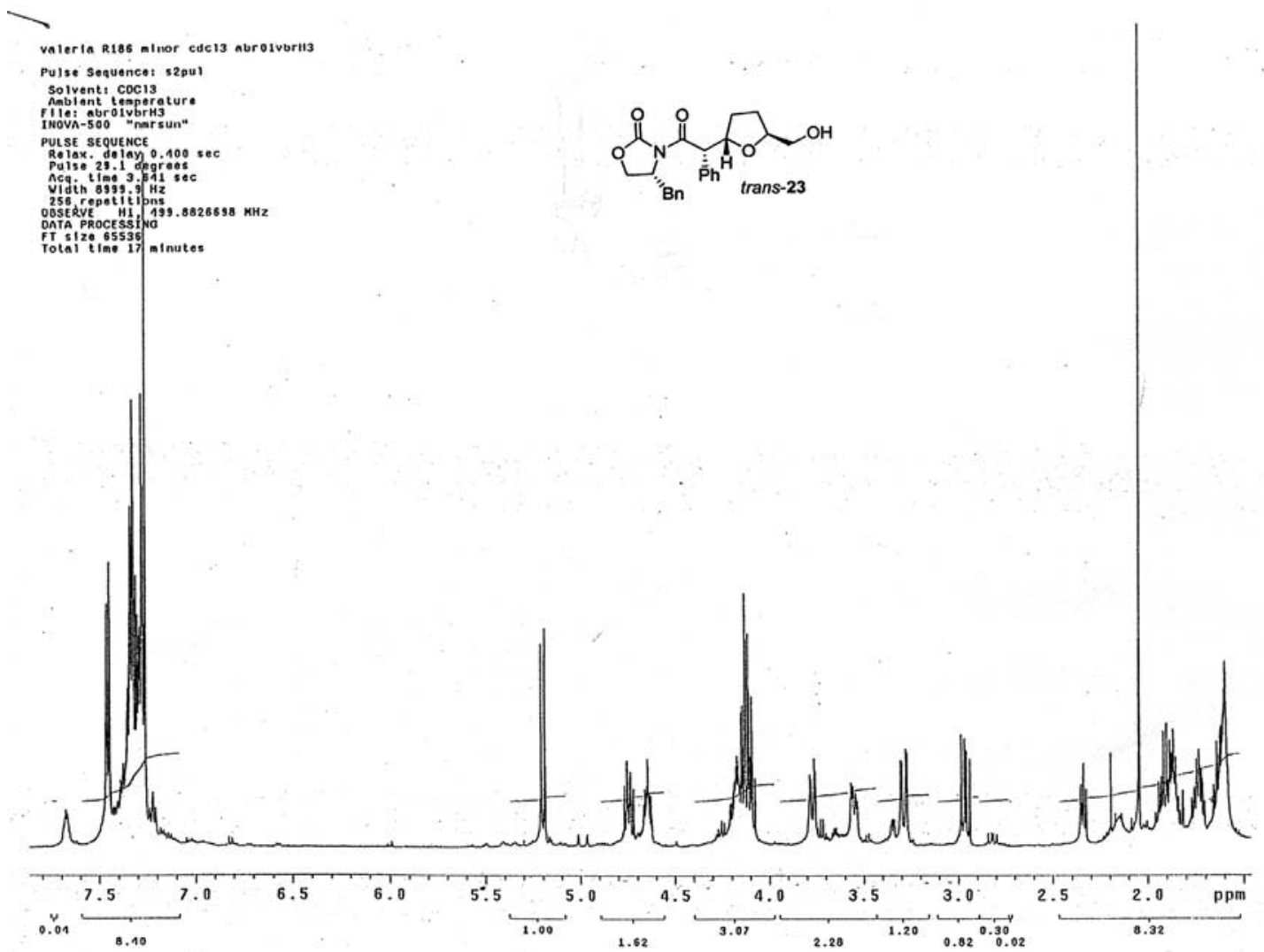

Figure S7. ${ }^{1} \mathrm{H}$ NMR spectrum of trans-23 $\left(500 \mathrm{MHz}, \mathrm{CDCl}_{3}\right)$ 


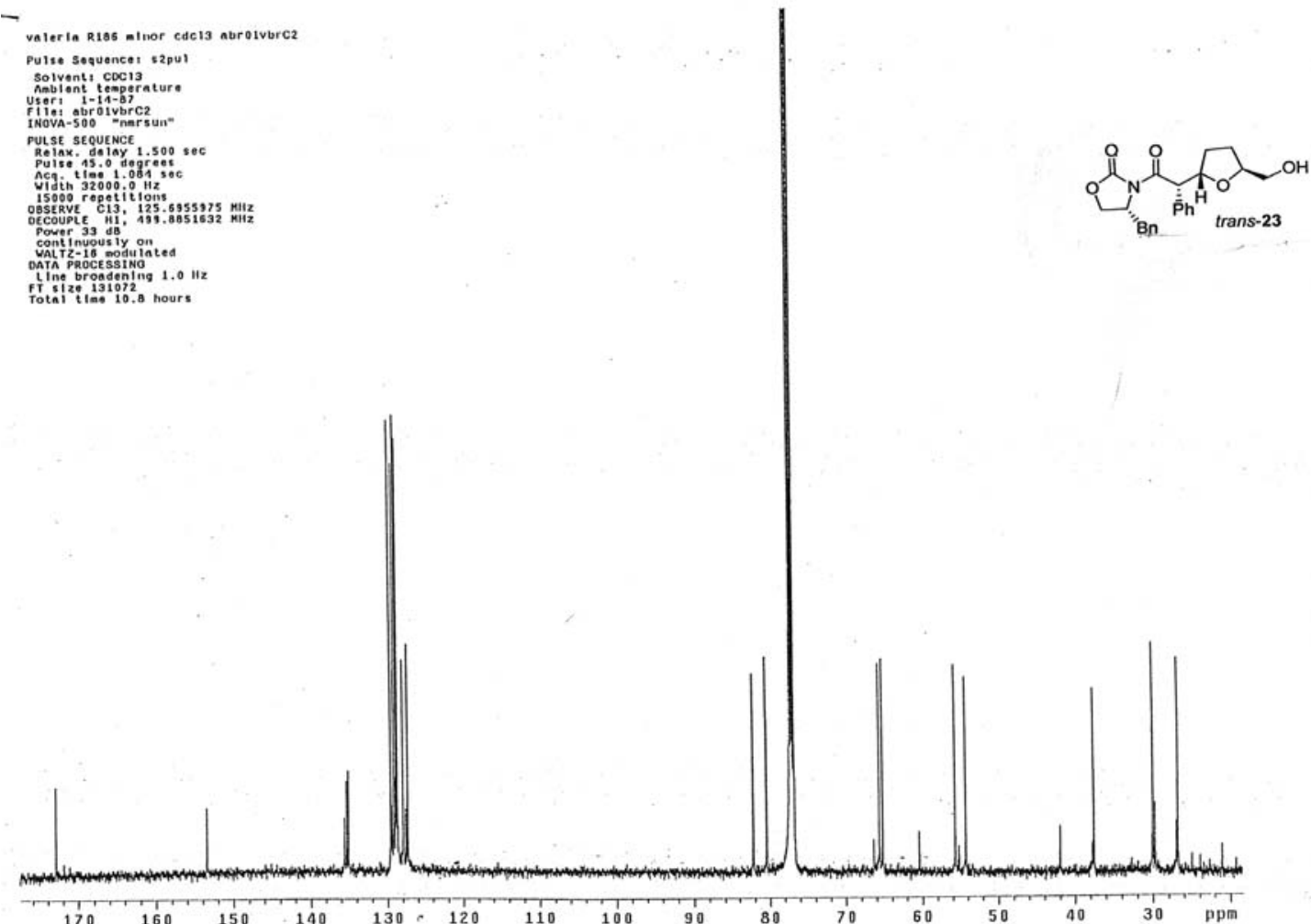

Figure S8. ${ }^{13} \mathrm{C}$ NMR spectrum of trans-23 $\left(125 \mathrm{MHz}, \mathrm{CDCl}_{3}\right)$

Valaria R243 codis setzova III

Pulsa Sequenco: s2pul

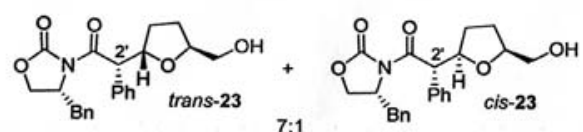

寅 ${ }^{\circ}{ }_{\text {cis-23 }}$

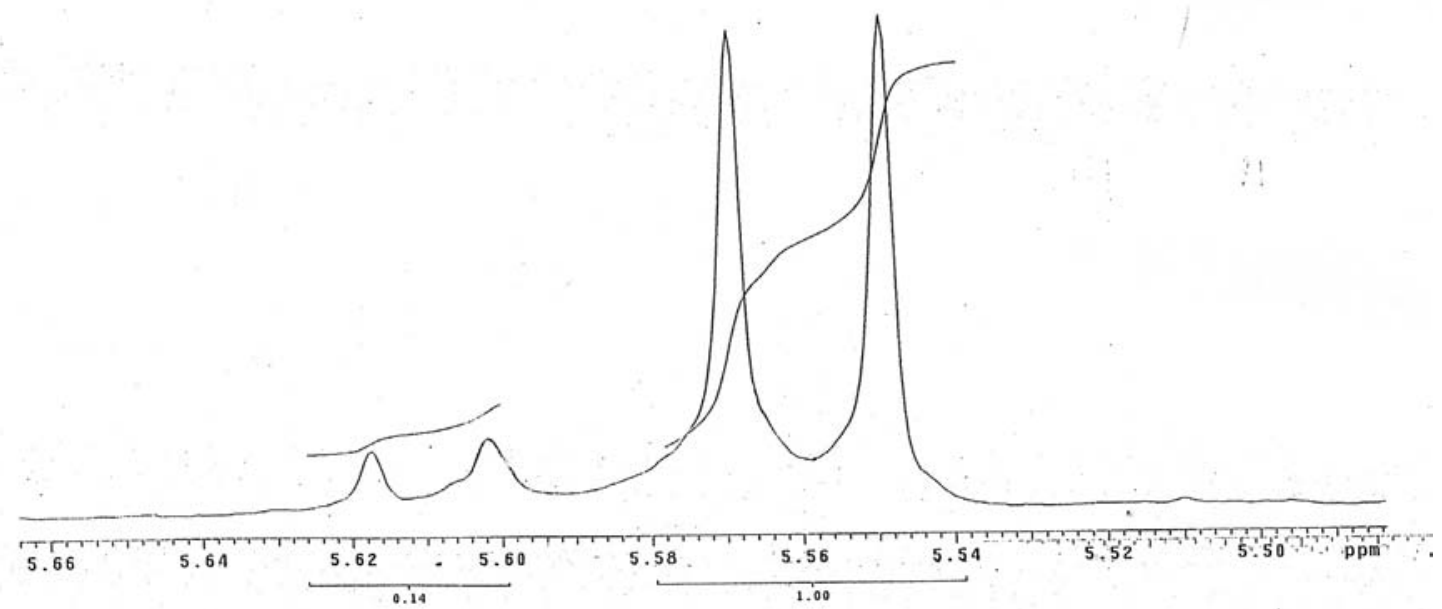

Figure S9. ${ }^{1} \mathrm{H}$ NMR spectrum of a crude mixture of trans-23/cis-23 $\left(\mathrm{C}_{6} \mathrm{D}_{6}, 500 \mathrm{MHz}\right)$ trans-23: $5.56\left(\mathrm{~d}, J 10.0 \mathrm{~Hz}, \mathrm{H}_{2}\right)$ and cis-23: $5.61\left(\mathrm{~d}, J 8.0 \mathrm{~Hz}, \mathrm{H}_{2}\right)$ 


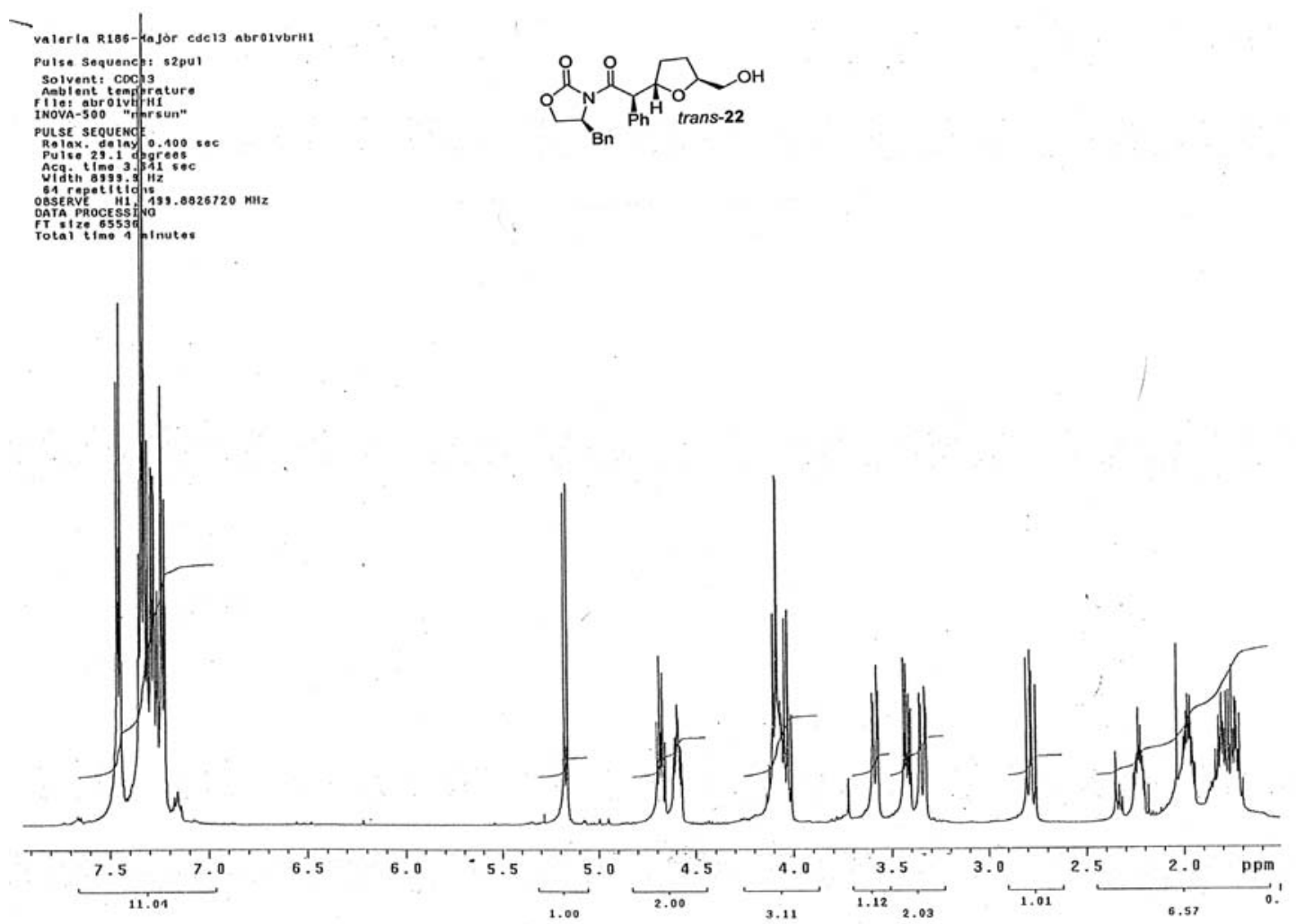

Figure S10. ${ }^{1} \mathrm{H}$ NMR spectrum of trans-22 $\left(500 \mathrm{MHz}, \mathrm{CDCl}_{3}\right)$

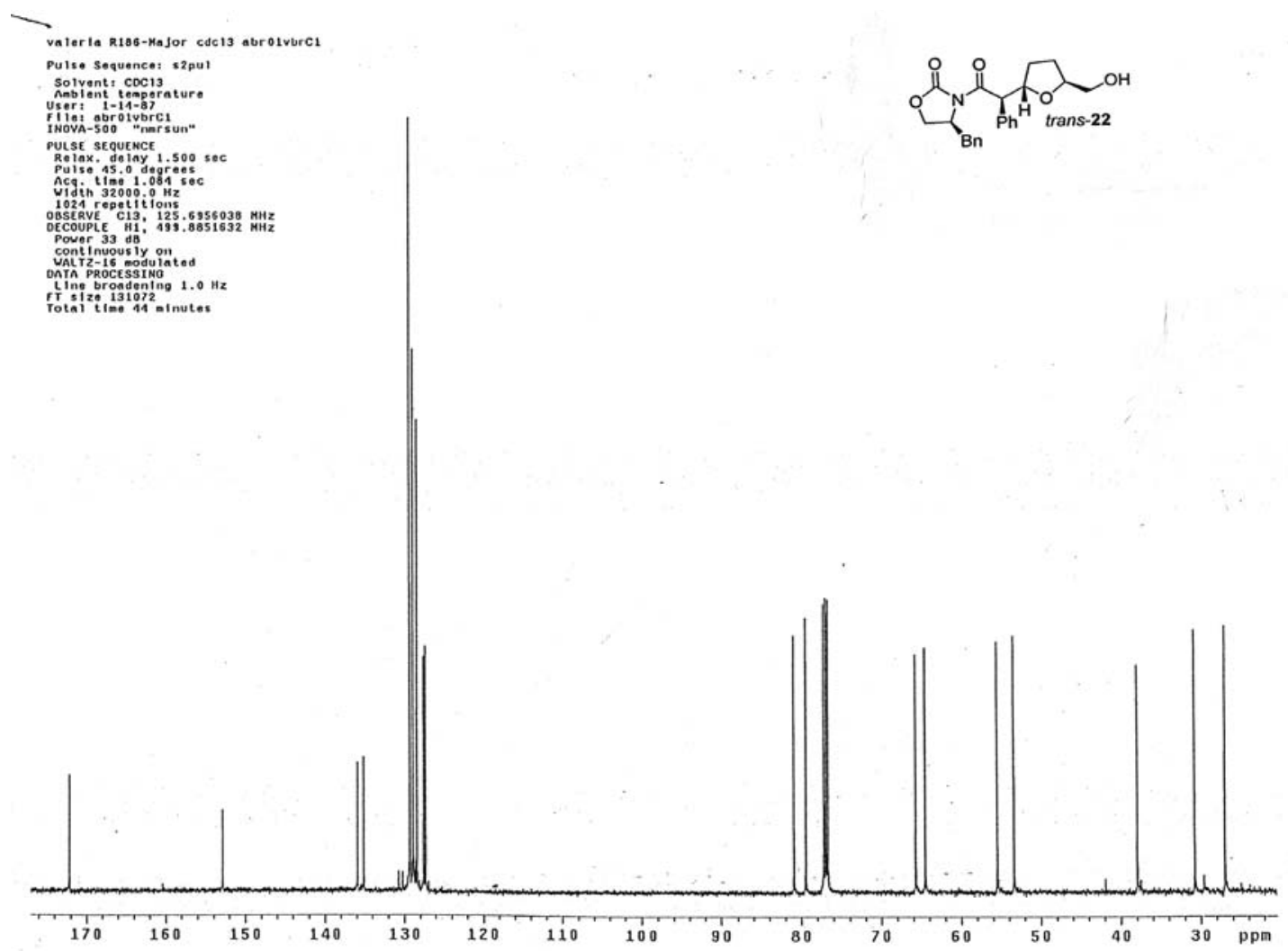

Figure S11. ${ }^{13} \mathrm{C}-\mathrm{NMR}$ spectrum of trans-22 $\left(125 \mathrm{MHz}, \mathrm{CDCl}_{3}\right)$ 


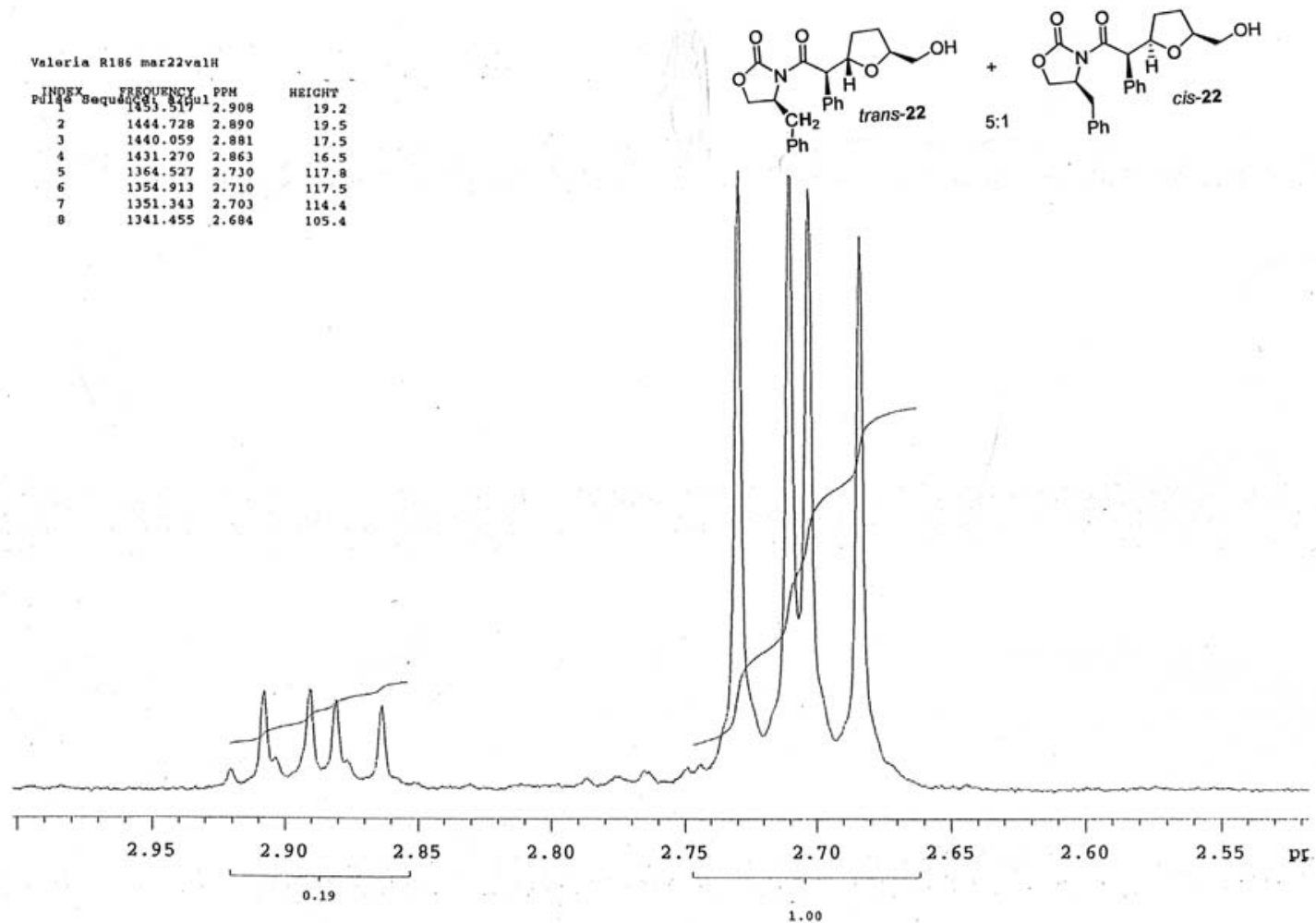

Figure S12. ${ }^{1} \mathrm{HNMR}$ spectrum of a crude mixture of trans-22/cis-22 ( $\left.\mathrm{CDCl}_{3}, 500 \mathrm{MHz}\right)$ trans-22:2.70(dd, J9.6, 13.4Hz, CH) and cis-22: 2.88(dd, J8.8, 13.4 Hz, CH)
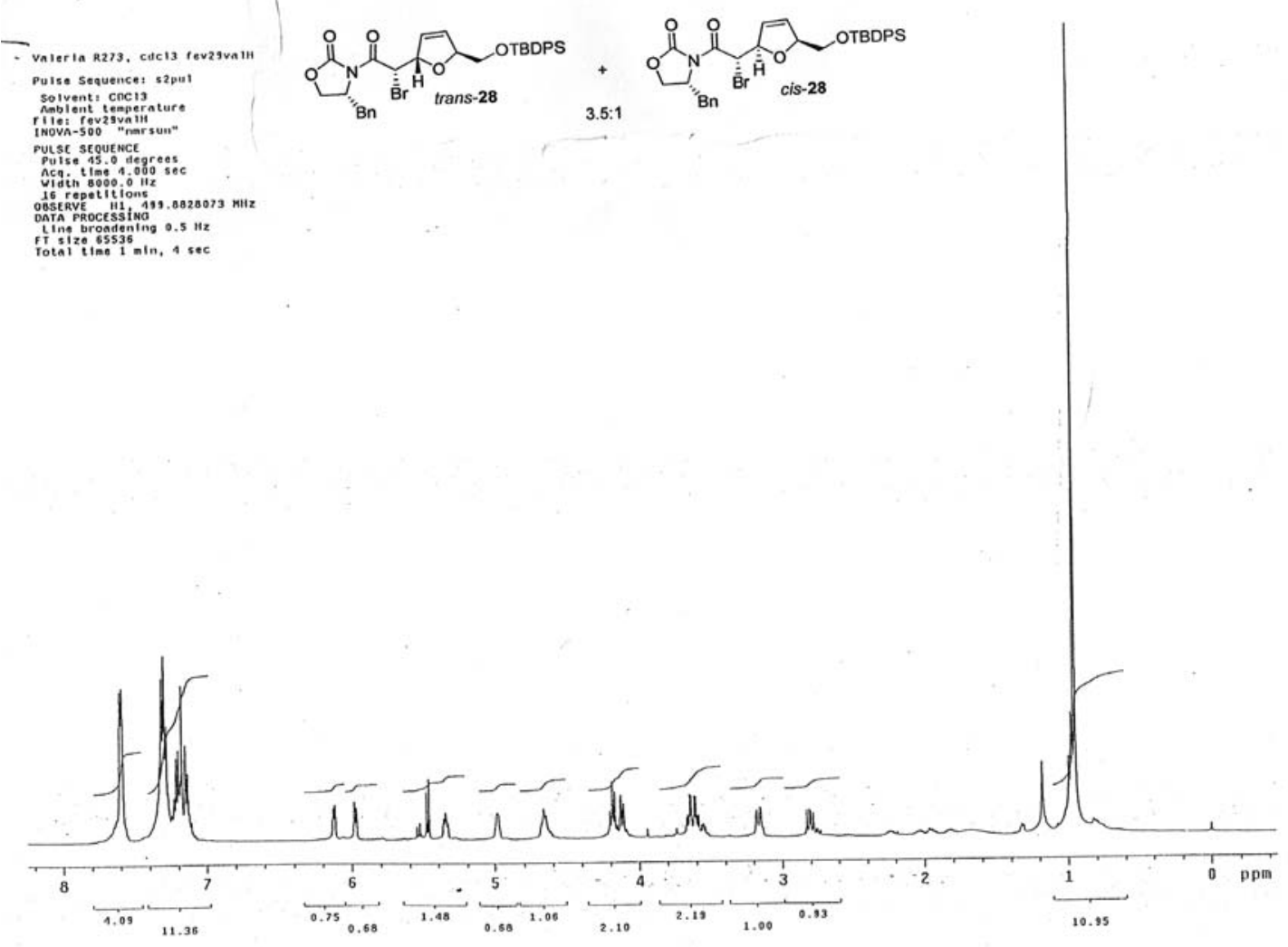

Figure S13. ${ }^{1} \mathrm{H}$ NMR spectrum of 3.5:1 trans-28/cis-28 mixture $\left(500 \mathrm{MHz}, \mathrm{CDCl}_{3}\right)$ 


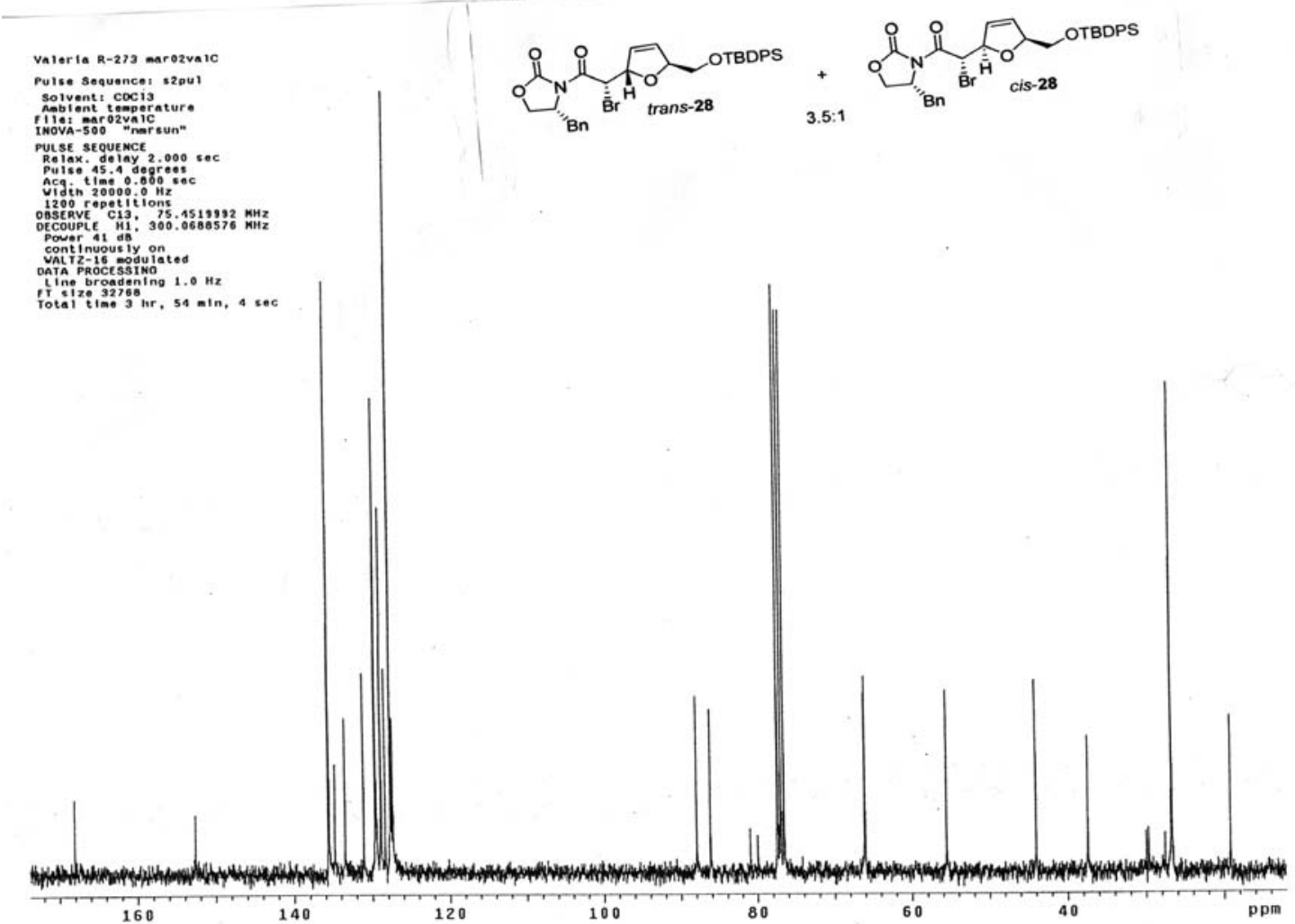

Figure S14. ${ }^{13} \mathrm{C}$ NMR spectrum of 3.5:1 trans-28/cis-28 mixture (75 $\left.\mathrm{MHz}, \mathrm{CDCl}_{3}\right)$

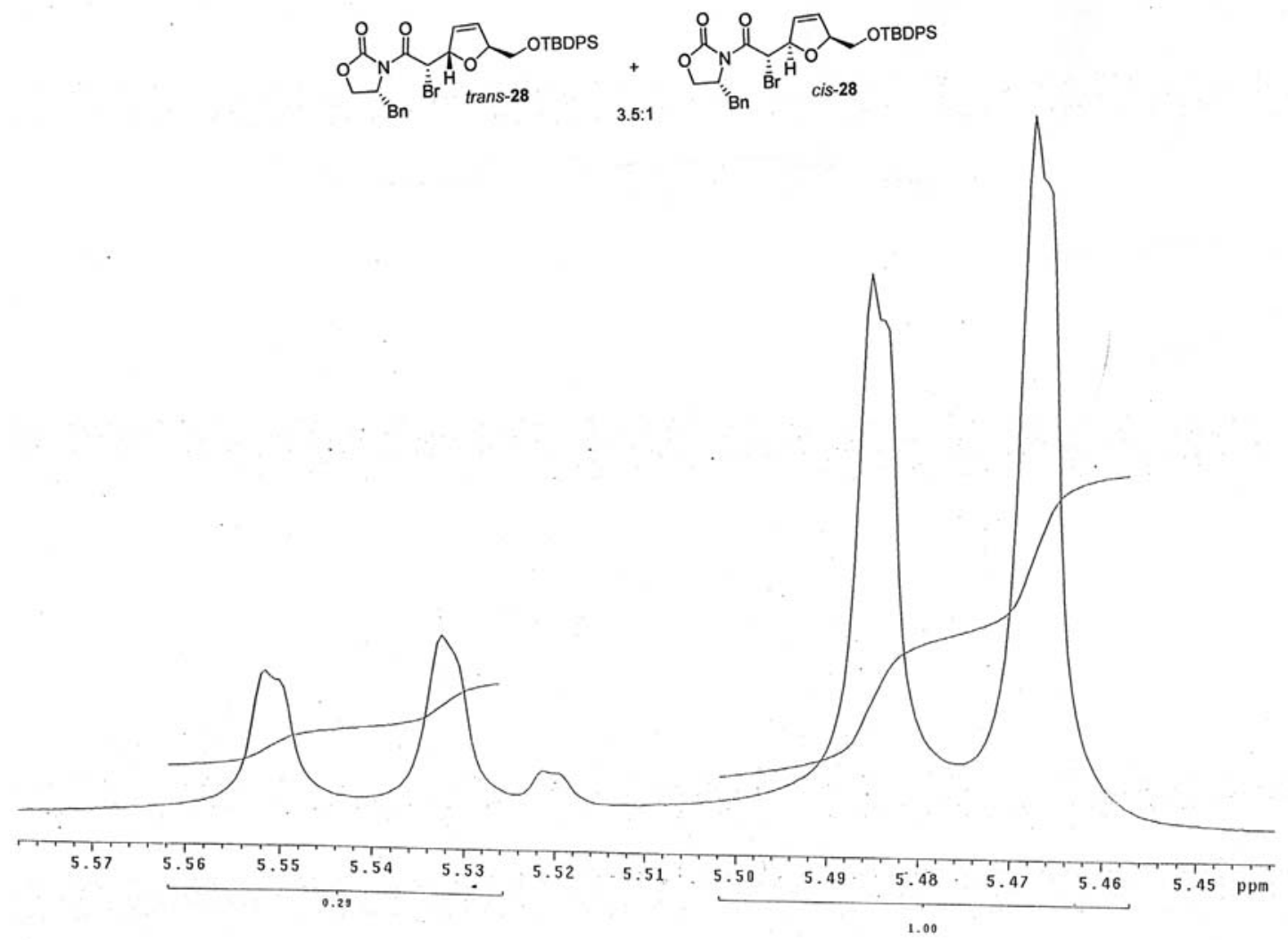

Figure S15. ${ }^{1} \mathrm{H}$ NMR spectrum of a crude mixture of trans-28/cis-28 $\left(\mathrm{CDCl}_{3}, 500 \mathrm{MHz}\right)$ trans-28: $5.47\left(\mathrm{~d}, J 8.0 \mathrm{~Hz}, \mathrm{H}_{2}\right)$ and cis-28: $5.54\left(\mathrm{~d}, J 9.5 \mathrm{~Hz}, \mathrm{H}_{2}\right)$ 


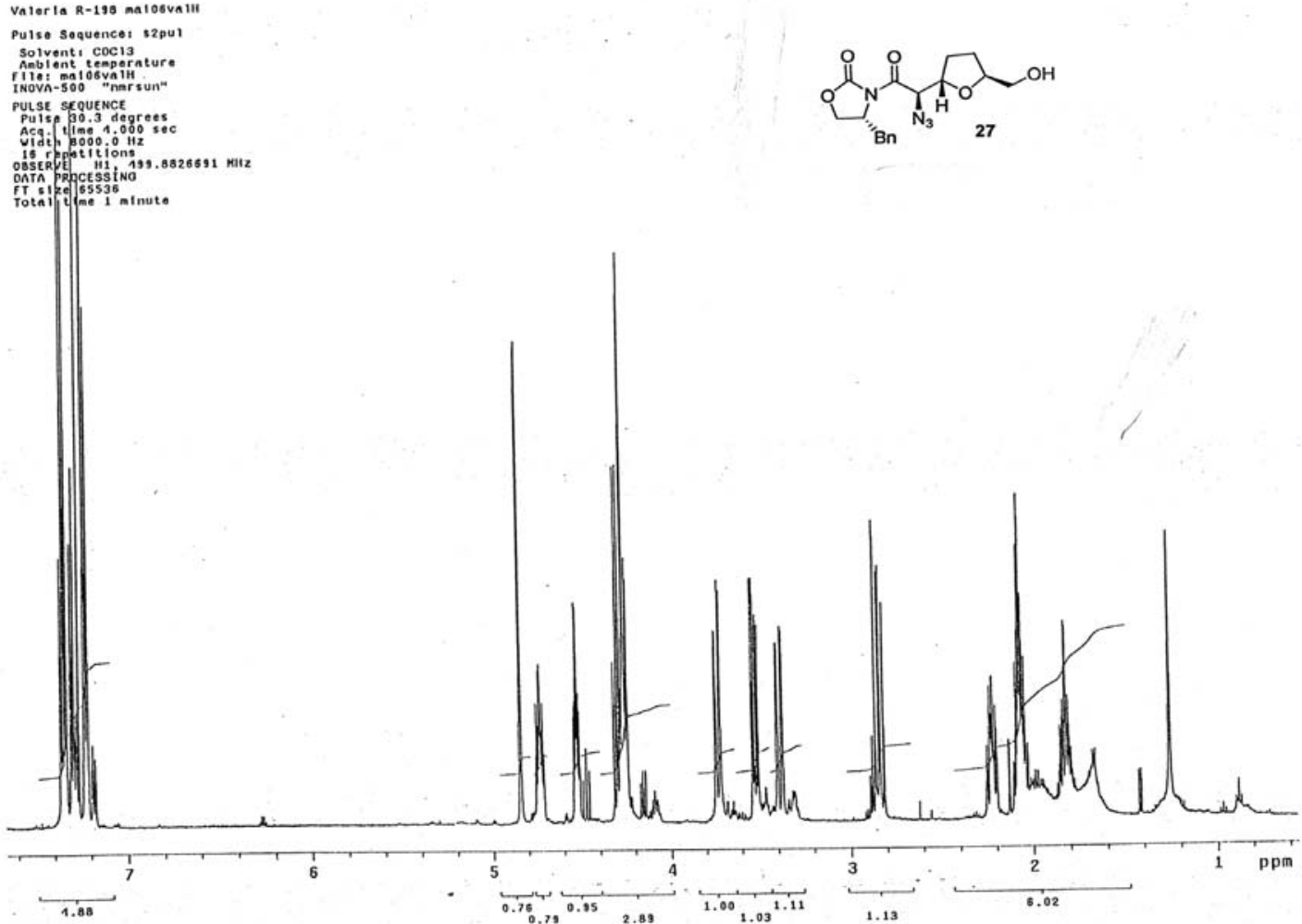

Figure S16. ${ }^{1} \mathrm{H}$ NMR spectrum of $27\left(500 \mathrm{MHz}, \mathrm{CDCl}_{3}\right)$

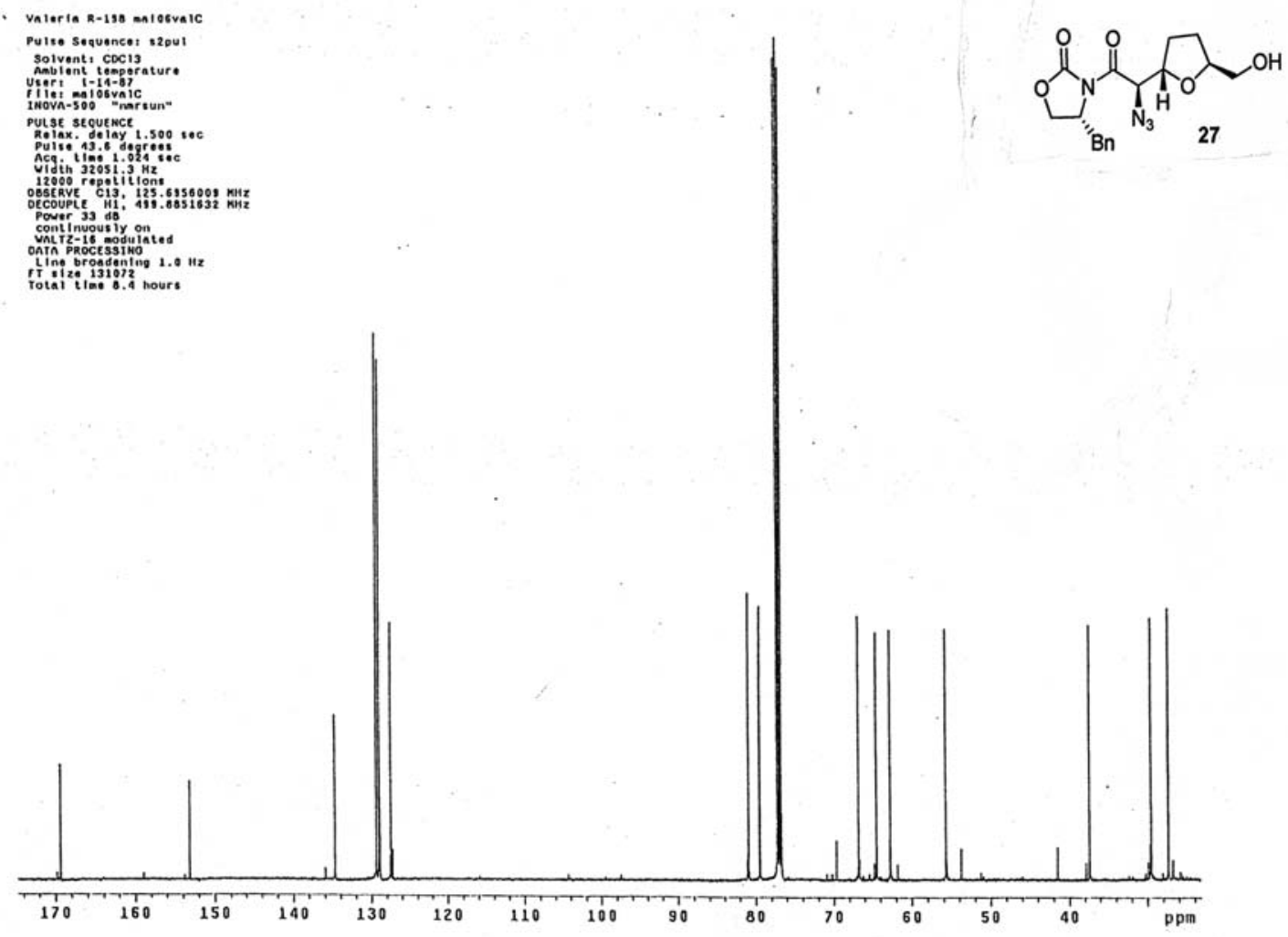

Figure S17. ${ }^{13} \mathrm{C}$ NMR spectrum of $27\left(125 \mathrm{MHz}, \mathrm{CDCl}_{3}\right)$ 